\begin{tabular}{|c|c|c|c|l|l|}
\hline \multirow{2}{*}{$\sim$} & S P P 2 & 1294 & \multirow{2}{*}{ WILEY } & Dispatch: 14.12.19 & CE: Geetha M \\
\cline { 2 - 3 } & Journal Code & Manuscript No. & & No. of pages: 28 & PE: Raymond Appavoo $M$. \\
\hline
\end{tabular}

[Papers in Palaeontology, 2019, pp. 1-28]

\title{
COMPARATIVE CRYSTALLOGRAPHY SUGGESTS MANIRAPTORAN THEROPOD AFFINITIES FOR LATEST CRETACEOUS EUROPEAN 'GECKOID' EGGSHELL
}

by SEUNG CHOI ${ }^{1, *}$ (D), MIGUEL MORENO-AZANZA² (D), ZOLTÁN CSIKI-SAVA ${ }^{3}$, 2 -1 EDINA PRONDVAI ${ }^{4,5}$ (D) and YUONG-NAM LEE ${ }^{1, *}$ (D)

${ }^{1}$ School of Earth \& Environmental Sciences, Seoul National University, Seoul 08826, South Korea; seung0521@snu.ac.kr, ynlee@snu.ac.kr

${ }^{2}$ Geobiotec, Departamento de Ciências da Terra, Universidade Nova de Lisboa, Caparica 2829-526, Portugal; mmazanza@fct.unl.pt

${ }^{3}$ Faculty of Geology \& Geophysics, University of Bucharest, Bucharest 010041, Romania; zoltan.csiki@g.unibuc.ro

${ }^{4}$ Department of Biology, Ghent University, Ghent 9000, Belgium; edina.prondvai@gmail.com

$3 \quad{ }^{5}$ Current address: MTA-MTM-ELTE Research Group for Paleontology, Budapest, 1083, Hungary

${ }^{\star}$ Corresponding authors

Typescript received 15 April 2019; revised 12 October 2019; accepted in revised form 31 October 2019

Abstract: Thin fossil eggshell from Upper Cretaceous deposits of Europe, characterized by nodular ornamentation similar to modern gekkotan eggshell, has mostly been inter-

4 preted as gekkotan (='geckoid') in origin. However, in some cases, as for the oogenus Pseudogeckoolithus, a theropod affinity has also been suggested. The true affinity of these fossil geckoid eggshells has remained controversial due to the absence of analytical methods for identifying genuine gecko eggshell in the fossil record. In this study, we apply electron backscatter diffraction (EBSD) analysis to latest Cretaceous European geckoid (including Pseudogeckoolithus) eggshell, in comparison with modern gekkotan and theropod (avian) eggshell. We found that Pseudogeckoolithus has a definite theropod eggshell-like crystallographic configuration, in clear contrast to that seen in modern geckos. Furthermore, the crystallography of the nodular ornamentation in Pseudogeckoolithus is similar to that seen in megapode eggshell, but different from that of gecko eggshell, despite superficial morphological similarity. The remarkable morphological similarities between Pseudogeckoolithus and modern gecko eggshells are thus convergent, and the 'gekkotan affinity' hypothesis can be dismissed for Pseudogeckoolithus. This study provides a template for differentiating true gekkotan from dinosaurian eggshells in the fossil record. The potential functional significance of eggshell ornamentation, lost in most modern birds, requires further study, and experimental zoological approach may shed light on this issue. Finally, the present results suggest caution about the dangers of using potentially homoplastic eggshell characters in eggshell parataxonomy.

Key words: eggshell, electron backscatter diffraction, gecko, homoplasy, ornamentation, theropod.
Fossil eggs and eggshells provide a unique opportunity to study aspects of the reproductive biology of extinct amniotes (e.g. Tanaka et al. 2015, 2019; Varricchio \& Jackson 2016; Amiot et al. 2017; Wiemann et al. 2018; Choi et al. 2019a). Among extant oviparous (egg-laying) amniotes, all archosaurs and some turtles lay rigid-shelled eggs, while the eggs of most lepidosaurs (squamates and rhynchocephalians) have a soft, leathery shell with a low degree of mineralization (Sander 2012; Skawiński \& Tałanda 2014). Because soft eggshell has a low preservation potential (Hirsch 1996), almost all previously studied fossil eggshells have been found to belong to archosaurs or chelonians. Nevertheless, there are also a small number of fossil squamate eggshell reports in the literature (Choi et al. 2019b, table S1). These shells are very thin and share similarities in their ornamentation - and in some cases also in their microstructure - with eggshells of Gekkota (Squamata), the only extant lepidosaurian clade besides the Dibamidae, with some of its members laying rigid-shelled eggs (Sander 2012; Skawiński \& Tałanda 2014), and with a fossil record dating back to the Early Cretaceous (Daza et al. 2014). Given that many maniraptoran (Dinosauria, Theropoda; a clade of bird-like theropods, including modern birds) eggshells are characterized by prismatic shell units (e.g. Mikhailov 1997a; Zelenitsky et al. 2002; Varricchio \& Jackson 2004) and modern gekkotan eggshells have a similar-looking jagged columnar structure (Schleich \& Kästle 1988; Packard \& Hirsch 
1989; Hirsch 1996; Mikhailov 1997a; Choi et al. 2018), the gekkotan or maniraptoran affinities of some fossil eggshells remained undecided. Thus, in the absence of in ovo embryos or at least body fossils in close association with the eggs or eggshells, there has been no rigorous way to test whether superficially gecko-like fossil eggshells are genuinely gekkotan or, in fact, archosaurian in origin.

Representative cases of fossil eggshell with such ambiguous identity were Pseudogeckoolithus and 'morphotype geckonoïde' (Vianey-Liaud \& Lopez-Martinez 1997; Garcia 2000) described from the upper Upper Cretaceous (Campanian-Maastrichtian) continental deposits of western Europe. These eggshells are characterized by dispersituberculate ornamentation, which is very similar to that of Gekko gecko (Gekkota) eggshell (Schleich \& Kästle 1988; Packard \& Hirsch 1989; Choi et al. 2018). According to Vianey-Liaud \& Lopez-Martinez (1997), Pseudogeckoolithus, as its name implies, is macroscopically similar to gecko eggshell, but its micro- and ultrastructural features were identified as a 'dinosauroid prismatic type', thus arguing for a dinosaurian origin. However, Garcia (2000) also reported gecko-like eggshells that are morphologically reminiscent of Pseudogeckoolithus but which she nevertheless referred to as morphotype geckonoïde, pointing out their microstructural similarity with extant gekkotan eggshell. Moreover, Sellés (2012) argued that even Pseudogeckoolithus lacks a mammillary layer and is merely composed of irregular prisms, hence, it is not of dinosaurian origin, but represents instead a Mesozoic lizard eggshell. Accordingly, European Late Cretaceous eggshells, which are very similar to either Pseudogeckoolithus or 'geckonoïde' eggshells, have been usually associated with Gekkota (e.g. Garcia \& VianeyLiaud 2001; Csiki-Sava et al. 2015, 2016; Botfalvai et al. 2017). In contrast, Prondvai et al. (2017) concluded recently that the most abundant fossil eggshells ('morphotype I' or 'MT I') from the Santonian of Iharkút, Hungary, which resemble both Pseudogeckoolithus and the French 'geckonoïde' morphotype, have a theropod affinity based on the presence of a mammillary layer, in agreement with Vianey-Liaud \& Lopez-Martinez (1997). Furthermore, Prondvai et al. (2017) suggested that, along with the Hungarian MT I eggshells, putative 'gecko-like' eggshells from the Upper Cretaceous deposits in Romania, Spain and France might have theropod affinities as well, consistent with the interpretation of North American dispersituberculate eggshells (e.g. Zelenitsky et al. 1996; Jackson \& Varricchio 2010, 2016; Table 1). These conflicting views on the nature of the Late Cretaceous geckoid eggshells can only be resolved with a diagnostic methodology that allows identification of genuine gekkotan eggshells in the fossil record.

Using electron backscatter diffraction (EBSD) analysis, Choi et al. (2018) showed that crystallographic configuration of extant gekkotan eggshell is fundamentally different from that of dinosaurian (including avian) eggshell (see Choi et al. 2019a, table 1). Hence, EBSD is adequate for differentiating gekkotan from theropod eggshell in the fossil record. Here, we apply EBSD analysis to different geckoid eggshell samples recovered from European Upper Cretaceous deposits in order to test their putative gekkotan affinity by comparing them with diverse sauropsid eggshells including those of extant Gekkota and Aves. During our study, we identified several distinct construction pathways of nodular eggshell ornamentation, and the parataxonomic importance of these is also discussed.

\section{GEOLOGICAL AND PALAEOGEOGRAPHICAL SETTING}

Vertebrate-bearing Upper Cretaceous (Santonian-Maastrichtian) continental beds are distributed discontinuously across a wide area in Europe (Csiki-Sava et al. 2015; Fig. 1A). These deposits were laid down in marginal marine, coastal plain or inland fluvial settings in an archipelago on the northern margin of the Neotethyan area. Although most of these former 'islands' yielded only few fragmentary fossils, some of them hosted a wide variety of vertebrate taxa. The most important of these is 'Bakony Island' in present-day western Hungary (with the Santonian Iharkút locality; Ösi et al. 2012; Botfalvai et al. 2016); 'Hațeg Island' in what is central-western Romania (with a number of localities ranging in age from the latest Campanian to the late Maastrichtian; Csiki-Sava et al. 2016); and the much larger 'Ibero-Armorican Landmass' covering the Iberian Peninsula and the southern part of present-day France (with numerous localities spanning the early Campanian - latest Maastrichtian time interval; e.g. Vila et al. 2016; Fondevilla et al. 2019). All three areas have yielded, besides diverse vertebrate remains, geckoid eggshells (Figs 1A, 2). We will review here briefly the general geological setting for these areas, as well as the geology and fossil content of the localities that yielded specimens used in the present study (for more details, see Choi et al. 2019b, texts S1, S2).

\section{Santonian of Iharkút, Hungary}

In Hungary, subaerially exposed fossiliferous Upper Cretaceous continental deposits are restricted to the Bakony region (Fig. 2A). These are grouped into two laterally interdigitating units: the mainly fluvial Csehbánya Formation, and the Ajka Coal Formation, deposited in coastal plain swamps (e.g. Haas et al. 1992; Botfalvai et al. 2016). These are represented by a variety of siliciclastic rocks, ranging from coarse conglomerates to marls and 


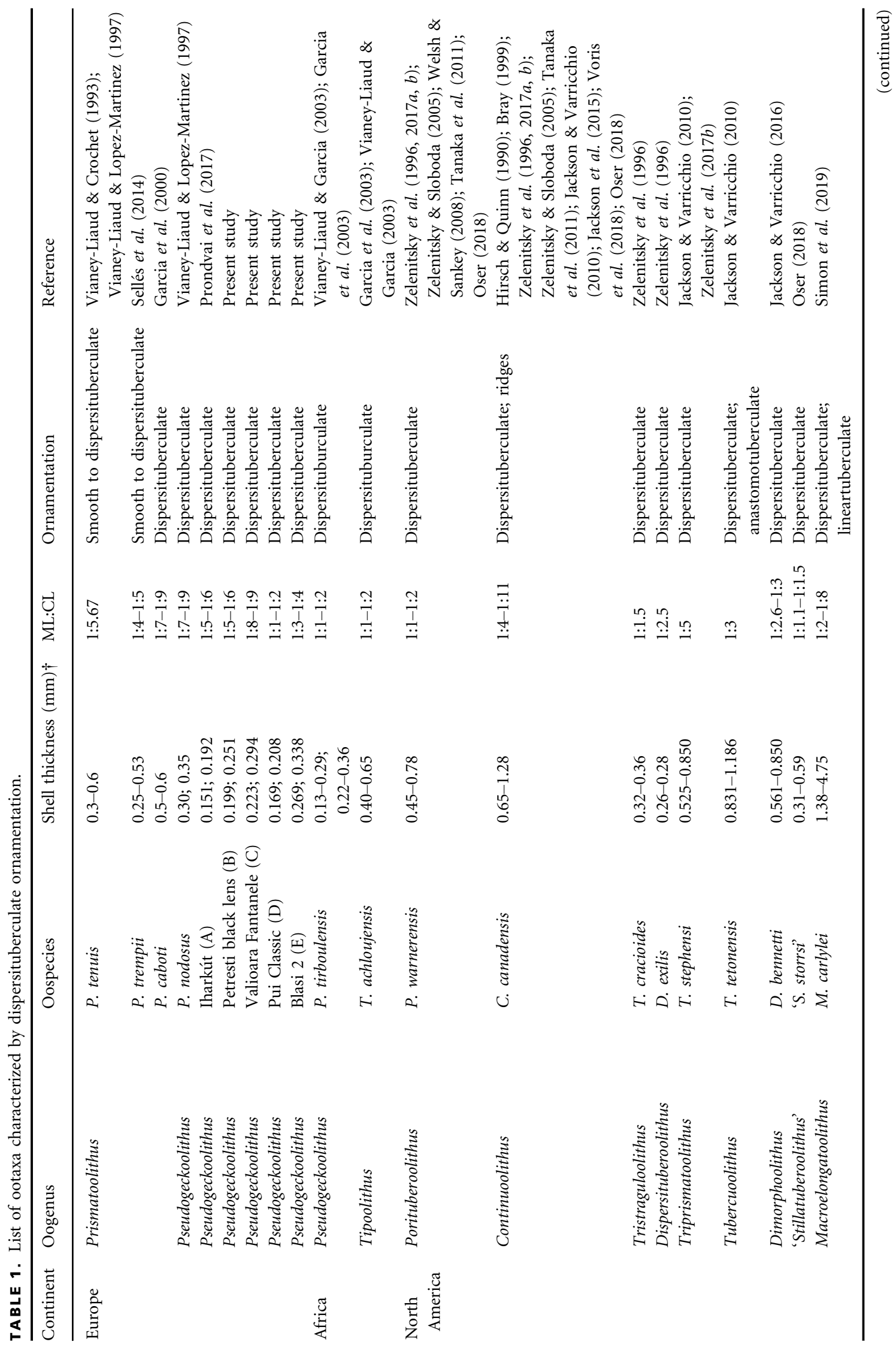


claystones. Minor coaly interbeds are present in the Csehbánya deposits, but are common in the Ajka beds. Their Santonian age (Fig. 1B) is based mainly on palynostratigraphy (e.g. Bodor \& Baranyi 2012) as well as on the biostratigraphically constrained latest Santonian-Campanian age of the overlying marine deposits (e.g. Haas 1983).

The most important fossils, representing a wide variety of vertebrate taxa (see Choi et al. 2019b, texts S1, S2), come from the Iharkút abandoned open-pit bauxite mine in the Csehbánya Formation (e.g. Ösi et al. 2012; Botfalvai et al. 2015). The vertebrate skeletal remains are occasionally associated with exclusively thin eggshell fragments (Botfalvai et al. 2015), among which Prondvai et al. (2017) identified different types of crocodyloid and theropod (including bird) eggshells, alongside a single fragment that was assigned to a squamate. Pseudogeckoolithus eggshell (see below, Systematic Palaeontology) is by far the most common, and the affinity was tentatively linked by Prondvai et al. (2017) to small-bodied theropods. These eggshells (named MT I morphotype in Prondvai et al. 2017 but here referred to Pseudogeckoolithus) occur in two different localities at Iharkút (e.g. Botfalvai et al. 2015): SZ-6, the main fossiliferous horizon, and SZ-7-8 (a pond deposit in a poorly drained floodplain; Botfalvai et al. 2016). The lithology at locality SZ-6 is interpreted as a flash-flood deposit within a fluvial channel, followed by slow infilling (Botfalvai et al. 2016). This locality (a high-diversity multitaxic macrovertebrate bonebed; Botfalvai et al. 2015) yielded the largest part of the vertebrates documented at Iharkút (see Choi et al. 2019b, text S2).

Uppermost Campanian-Maastrichtian of Transylvania, Romania

Upper Cretaceous continental beds are widespread but occur patchily in western Romania, most importantly in the Hațeg Basin (Figs 1A, 2B). The litho- and chronostratigraphy, as well as the fossil content of these deposits, were recently reviewed by Csiki-Sava et al. (2015), and are briefly synthesized here. The continental beds are largely siliciclastic, ranging from coarse conglomerates to siltstones and mudstones. Locally, igneous products are also present within the successions, whereas other rock types are rare, except the Rusca Montană Basin where coal intercalations are known. Deposition took place in fluvially dominated environments, under a seasonally variable, dominantly semi-arid climate. The latest Campanian-Maastrichtian age of these deposits is constrained by biostratigraphically dated underlying marine beds (Melinte-Dobrinescu 2010; Vremir et al. 2014), and is corroborated by radiometric aging (Bojar et al. 2011), palynostratigraphy (Antonescu et al. 1983; Van Itterbeeck et al. 2005) and magnetostratigraphy (Panaiotu \& Panaiotu 2010). 


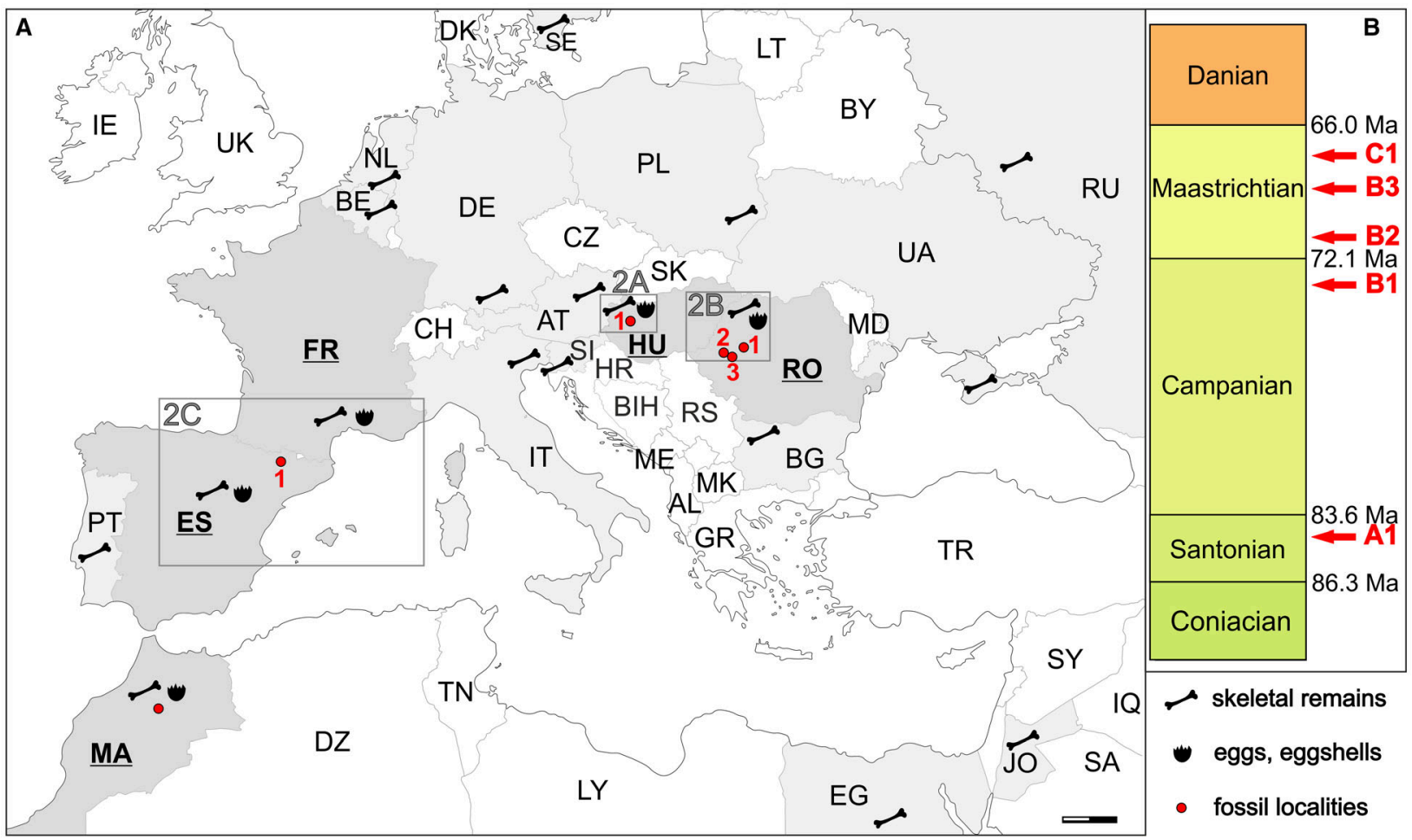

FIG. 1. Latest Cretaceous continental vertebrate distribution in the peri-Mediterranean area, with selected Pseudogeckoolithus localities (for more detail, see Fig. 2 and Choi et al. 2019b, texts S1, S2). A, outline map marking countries with latest Cretaceous continental vertebrate remains (highlighted in light grey), eventually associated with eggshells (dark grey). Distribution map based on Garcia et al. (2003), Weishampel et al. (2004), Chassagne-Manoukian et al. (2013), Csiki-Sava et al. (2015), Sallam et al. (2016, 2018), and Longrich et al. (2017). Standardized country abbreviations follow the ISO alpha-2 system (https://www.iso.org/iso-3166-country-codes. html). Boxes highlight the geographical position of the Pseudogeckoolithus fossil localities discussed in this paper, as well as the type locality of the Moroccan Pseudogeckoolithus tirboulensis (Vianey-Liaud \& Garcia 2003; Achlouj 2 locality). Boxes 2A, Santonian locality SZ-6 in Iharkút (A1), western Hungary (former 'Bakony Island'); 2B, latest Campanian-Maastrichtian localities Petrești-Black Lens (B1), Vălioara-Fântânele (B2) and Pui-Classic (B3), in western Romania (former 'Hațeg Island'); and 2C, late Maastrichtian locality Blasi 2 (C1), in southern France-central-northern Spain (former 'Ibero-Armorican Landmass'). B, approximate stratigraphic position of the sampled Pseudogeckoolithus localities. A1-C1 denote fossil localities according to their respective boxes (A-C in A). Scale bar represents $200 \mathrm{~km}$.

A rich assemblage of continental organisms is known from these deposits, including invertebrates, plants and vertebrates, the latter - best represented in the Hațeg Basin (Fig. 2B-e) - known for the dwarf dinosaurs (Benton et al. 2010; Csiki-Sava et al. 2015; Choi et al. 2019b, texts S1, S2). The vertebrate skeletal remains are sometimes associated with eggs and eggshell fragments. Besides megaloolithids of a contentious affinity (e.g. Grigorescu et al. 2010; Grellet-Tinner et al. 2012; Botfalvai et al. 2017), diverse thin eggshells are also present, but have remained mainly unstudied (Codrea et al. 2002; CsikiSava et al. 2008; Dyke et al. 2012), with the exception of a peculiar mixed assemblage of avian, crocodyloid and gekkotan eggshells (Fernández et al. 2019). Of these thin eggshells, the most commonly occurring ones belong to Pseudogeckoolithus (e.g. Codrea et al. 2010a; Vremir et al. 2015a; see below, Systematic Palaeontology), although frequently they were only referred to as geckoid or geckonoid (e.g. Codrea et al. 2002; Csiki-Sava et al. 2008, 2016). Three new Pseudogeckoolithus occurrences - one from the southwestern Transylvanian Basin and two from the Hațeg Basin - are reported here for the first time (Figs 1, 2B), and are described briefly in ascending order of age (see also Choi et al. 2019b, text S2).

The oldest locality is the Petrești-Black Lens microvertebrate bonebed $(\mathrm{MvBB})$ in the Transylvanian Basin (Figs 1, 2B) from the Petrești-Arini section (Codrea et al. 2010a; Vremir 2010), a unique marine-to-continental transitional sequence spanning the latest Campanian - earliest Maastrichtian interval (e.g. Vremir et al. 2014); the recently identified Black Lens MvBB is probably latest Campanian in age (Vremir et al. 2015b). The $\mathrm{MvBB}$ is a poorly drained coastal plain deposit that yielded a rich assemblage of aquatic and terrestrial 


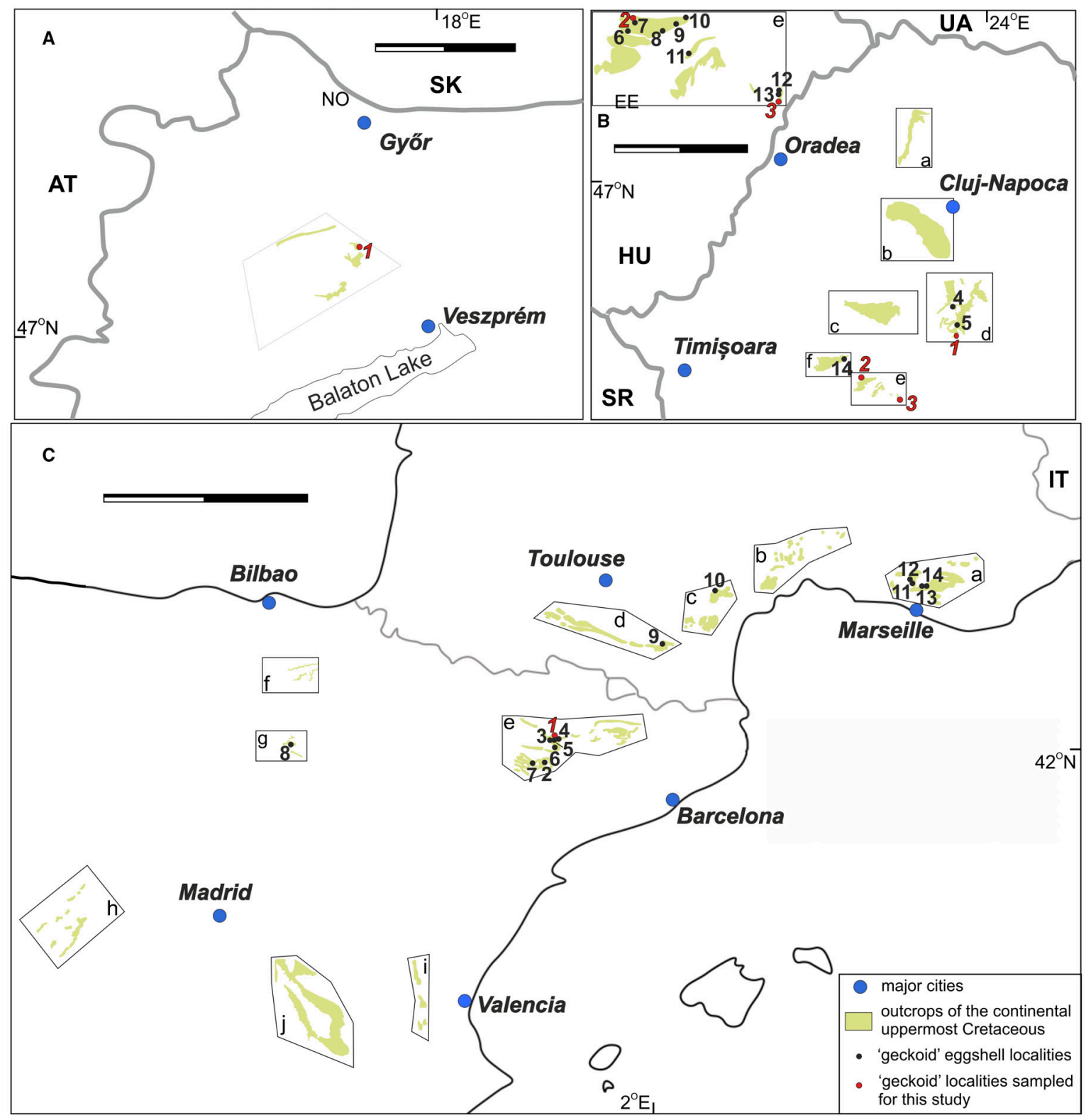

FIG. 2. Distribution of 'geckoid' (including both Pseudogeckoolithus and morphotype geckonoïde) eggshell-bearing localities in the uppermost Cretaceous (Santonian-Maastrichtian) of southern Europe (see Fig. 1), overlain on the approximate areal distribution of the main uppermost Cretaceous continental deposit outcrops (based on Haas et al. 1992; Pol et al. 1992; Ortega et al. 2015; Csiki-Sava et al. 2016; Corral et al. 2016; Pérez-García et al. 2016; Vila et al. 2016). A, Santonian, Hungary: 1, Iharkút localities Sz-6 and Sz 7-8 (Ősi et al. 2012; Botfalvai et al. 2016). B, uppermost Campanian-Maastrichtian, Romania: a, northwestern Transylvanian Basin; b, western Transylvanian Basin; c, Southern Apuseni Mountains; d, southwestern Transylvanian Basin; e, Hațeg Basin (also shown as enlarged inset); and f, Rusca Montană Basin. Localities: 1, Petrești-Black Lens (present study); 2, Vălioara-Fântânele (present study); 3, Pui-Classic (present study); 4, Oarda de Jos A (Codrea et al. 2010a, b, c; Vremir 2010; Vremir et al. 2015a); 5, Sebeș-Glod (Vremir et al. 2015a); 6, Ciula Mică (Vasile 2010); 7, Budurone (Csiki-Sava et al. 2008); 8, Tuștea (Botfalvai et al. 2017); 9, General Berthelot BG-1 (Vasile et al. 2011a); 10, Crăguiș (Vasile et al. 2011b); 11, Totești (Codrea et al. 2002); 12, Pui Swamp (Voicu et al. 2018); 13, Pui Islaz (Garcia et al. 2002); 14, Fărcădeana (Vasile \& Csiki-Sava 2011; Vasile et al. 2012; Csiki-Sava et al. 2016). C, Campanian-Maastrichtian, southern France and north-central Spain: a, Arc Basin; b, Hérault; c, Corbières-Haute Valley of Aude; d, Plantaurel-Haute Garonne; e, Southern Pyrenean Foredeep; f, Basque Country-Laño; g, Burgos Province; h, Segovia Province; i, Valencia area; j, Cuenca Province. Localities: 1, Blasi 2 (present study); 2, Fontllonga 6 (Vianey-Liaud \& Lopez-Martinez 1997); 3, Serrat del Pelleu (Sellés 2012); 4, Molí del Baró (Sellés 2012); 5, Serrant del Rostià (Sellés 2012); 6, Camí del Soldat (Sellés 2012); 7, L’Espinau (Sellés 2012); 8, Quintanilla del Coco (Garcia 2000); 9, Rennes-leChateau (Cousin 1997); 10, Cruzy (Garcia 2000); 11, Vitrolles-Couperigne (Garcia 2000); 12, Vitrolles-La-Plaine (Valentin et al. 2012); 13, Trets (Kerourio 1982); 14, Le Neuve (Garcia 2000). Scale bars represent 50 km (A); 100 km (B); 200 km (C). 
vertebrates (Vremir et al. 2015b), besides eggshell fragments, gastropods and charred wood remains.

In the Hateg Basin, the chronostratigraphically older locality is the early Maastrichtian Vălioara-Fântânele locality (Figs 1, 2B; Grigorescu et al. 1999; Csiki-Sava et al. 2016). It was formed in a small depression with ponded, oxygen-poor waters, developed within the confines of a braided river floodplain (Vasile \& Csiki-Sava 2010). The fossil accumulation is a classical MvBB with a rich and diverse vertebrate assemblage (Csiki-Sava et al. 2016; Choi et al. 2019b, text S2). These are associated with invertebrates and eggshells, including common geckoid (= Pseudogeckoolithus; see Systematic Palaeontology) ones.

The third, and geologically youngest, Romanian locality surveyed in the present study (Pui-Classic; Figs 1, 2B) is located near Pui; it is most probably late (although probably not latest) Maastrichtian in age (Csiki-Sava et al. 2016; Choi et al. 2019b, text S2). The fossiliferous bed formed in a well-drained floodplain setting, and represents a typical MvBB dominated by shed archosaur teeth, associated with other organic remains including common geckoid eggshells.

Campanian-Maastrichtian of northern Spain and southern France

Upper Cretaceous continental and transitional deposits are widespread in central and northern Spain (most importantly in the Southern Pyrenean Foredeep, where they are represented by the Arén and Tremp formations: red and grey marls and clays, sandstones with local limestone levels; Mey et al. 1968), as well as in southern France (e.g. CsikiSava et al. 2015) (Figs 1, 2C). These deposits represent the lowermost Campanian - uppermost Maastrichtian interval in southern France, and the Campanian - uppermost 8 Maastrichtian in Spain, and are usually divided into local chronostratigraphic units that are often difficult to correlate with the standard chronostratigraphic divisions (e.g. Cojan \& Moreau 2006; Csiki-Sava et al. 2015). Given that the Pyrenean area includes $\mathrm{K}-\mathrm{Pg}$ boundary continental outcrops, a large number of magnetostratigraphic and biostratigraphic studies have been carried out in recent years, resulting in a detailed, although somewhat controversial, chronostratigraphic framework for the uppermost Cretaceous continental deposits (Fondevilla et al. 2016, 2019; Puértolas-Pascual et al. 2018).

The continental uppermost Cretaceous of Ibero-Armorica has yielded an important and diverse tetrapod fauna, including clutches, eggs and nests of several species of dinosaurs and crocodyliforms (Csiki-Sava et al. 2015; Sellés \& Vila 2015; Canudo et al. 2016 and references therein). Most importantly, the oogenus Pseudogeckoolithus itself was erected from the early Maastrichtian aged Fontllonga 6 locality, within the Southern Pyrenean Foredeep (Vianey-Liaud \& Lopez-Martinez 1997; Fig. 2C), and was subsequently identified in several other localities across the Southern Pyrenees (e.g. Sellés 2012) that span the early - late Maastrichtian interval (Fondevilla et al. 2016, 2019), including the late Maastrichtian Blasi 2 locality (Pereda-Suberbioloa et al. 2009; MorenoAzanza et al. 2014a). Furthermore, Pseudogeckoolithus or geckoid eggshells (often identified as morphotype geckonoïde by Garcia 2000) were also reported from the Maastrichtian Spanish Quintanilla del Coco locality (Fig. 2C; Pol et al. 1992), as well as from several localities spread across southern France (e.g. Kerourio 1982; Cousin 1997; Garcia 2000; Valentin et al. 2012; Fig. 2C).

Materials included in this study come from the Blasi 2 locality, an MvBB located on the northern flank of the Tremp Syncline (Southern Pyrenean Foredeep; Figs 1, 2C). It yielded a diverse vertebrate assemblage (LópezMartínez et al. 2001; Blain et al. 2010; Torices et al. 2015) besides eggshell fragments (Moreno-Azanza et al. 2014a), including geckoid (Pseudogeckoolithus, see below, Systematic Palaeontology) eggshells as well.

\section{MATERIAL AND METHOD}

\section{Late Cretaceous Pseudogeckoolithus}

The most characteristic feature of the oogenus Pseudogeckoolithus, erected by Vianey-Liaud \& Lopez-Martinez (1997) based on six eggshell fragments collected from the early Maastrichtian (magnetochron C31N) Fontllonga-6 locality (Lleida Province, Spain), is its dispersituberculate ornamentation. Although the holotype fragments are seemingly lost, this oogenus has been identified in several other localities across Ibero-Armorica (see review in Choi et al. 2019b, text S2; Fig. 2), as well as in northern Africa (Morocco; Vianey-Liaud \& Garcia 2003; Fig. 1). On its turn, the geckonoïde eggshell type described by Garcia (2000) is also very similar to Pseudogeckoolithus and may well be synonymous with this oogenus.

For this study, eggshell fragments showing dispersituberculate ornamentation almost identical to that of Pseudogeckoolithus and of the dinosaur prismatic morphotype were selected from three main European regions with important uppermost Cretaceous continental outcrops (Hungary, Romania and Spain; Csiki-Sava et al. 2015) (Figs 1-3; Choi et al. 2019b, text S2). Although unfortunately we could not access French geckonoïde material (e.g. Garcia 2000) for our analysis, hereafter, we collectively refer to all dispersituberculate European eggshells, including Pseudogeckoolithus, the unavailable French geckonoïde type and our eggshell samples, as 'geckoid' (between single quotation marks to avoid confusion with the Geckoid basic type and morphotype of 
Mikhailov 1997a). Furthermore, despite their relatively diverse appearance (Table 1), all dispersituberculate eggshells included in this study are relatively thin $(<350 \mu \mathrm{m}$, including ornamentation) and show pore openings at the top of some of the ornamental nodes (Fig. 3), which are further diagnostic features of the oogenus Pseudogeckoolithus.

From the specimens included in this study, the 'geckoid' eggshells from the Romanian locality of VălioaraFântânele and the Spanish locality of Blasi 2 (Fig. 3C, E) are thicker and have less dense ornamentation than specimens from the Hungarian locality of Iharkút and the Romanian localities of Petrești-Black Lens and Pui-Classic (Fig. 3A, B, D). Therefore, the former specimens are referred to as Pseudogeckoolithus cf. nodosus (VianeyLiaud \& Lopez-Martinez 1997), whereas the latter as Pseudogeckoolithus aff. tirboulensis (Vianey-Liaud \& Garcia 2003) (see below, Systematic Palaeontology).

Institutional abbreviations. LPB [FGGUB], Laboratory of Paleontology, Faculty of Geology and Geophysics, University of Bucharest, Bucharest, Romania; MPZ, Museo Paleontológico de la Universidad de Zaragoza, Zaragoza, Spain (Canudo 2018); MTM, Hungarian Natural History Museum, Budapest, Hungary.

\section{Fossil comparative materials}

In order to narrow down the possible dinosaurian taxonomic affinities of Pseudogeckoolithus, EBSD images of several types of dinosaur fossil eggshells were analysed and compared with Late Cretaceous Pseudogeckoolithus. These include hadrosaur (cf. Maiasaura), sauropod (Megaloolithus cf. siruguei), troodontid (Prismatoolithus levis) and enantiornithine (Gobioolithus minor) eggshells. The EBSD images of the hadrosaur and sauropod eggshells were already presented in Moreno-Azanza et al. (2013) and Moreno-Azanza et al. (2016), respectively. Although the sauropod eggshell example discussed in Moreno-Azanza et al. (2016) shows sufficiently well the overall crystallography of a typical sauropod eggshell, it was nonetheless significantly altered by taphonomic effects, thus we recommend to inspect the EBSD image of a well-preserved sauropod eggshell figured in Grellet-Tinner et al. (2011) and Eagle et al. (2015) as well. The EBSD images of the troodontid and enantiornithine eggshells are provided as representatives of confirmed maniraptoran eggshells; only brief accounts of these two maniraptoran eggshell types are provided here, given that a detailed description was given in Choi et al. (2019a).
A
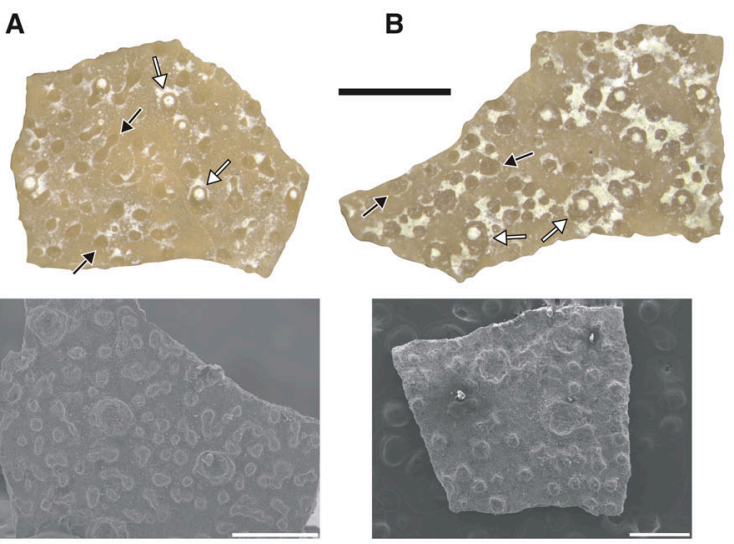

D

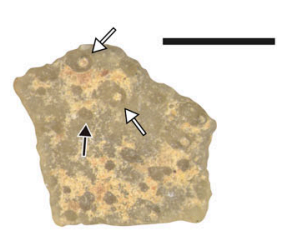

E
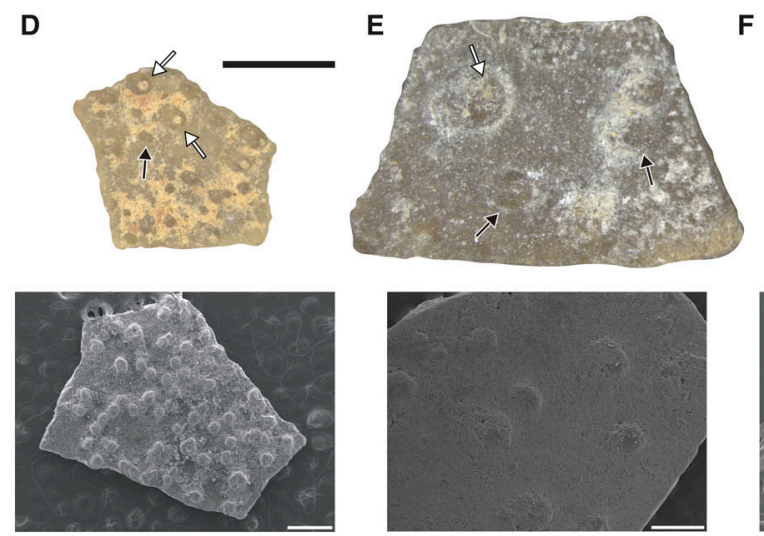

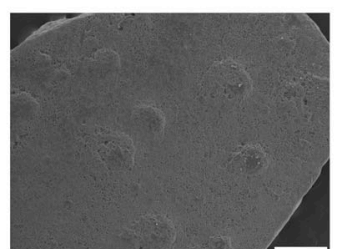

C
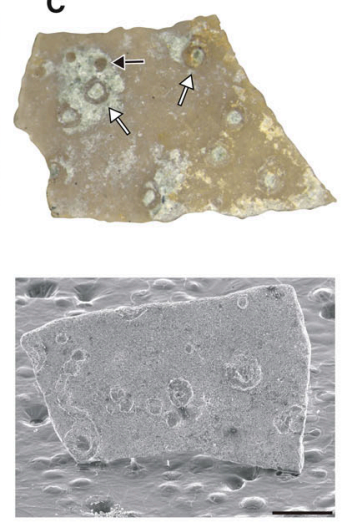

$\mathbf{F}$
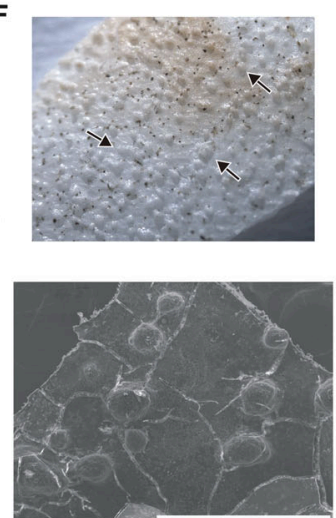

FIG. 3. European Late Cretaceous Pseudogeckoolithus specimens and extant gecko eggshell, on stereomicroscopy (upper row) and scanning electron microscopy (SEM; lower row), respectively. A, MTM VER 2015. 336a-b, Iharkút. B, LPB [FGGUB] R.2668.3-4, Petrești-Black Lens. C, LPB [FGGUB] R.2669.6-7, Vălioara-Fântânele. D, LPB [FGGUB] R.2672.4-5, Pui-Classic. E, MPZ 2019/573, Blasi 2. F, External view of Gekko gecko (Gekkota) eggshell. The dispersituberculate ornamentation and the presence of crater-like (sensu Prondvai et al. 2017) aspect of the nodes are marked by black and white arrows, respectively. Note the absence of crater-like ornamentation in Gekko gecko eggshell. Scale bars represent $1 \mathrm{~mm}$ (stereomicroscopy images); $500 \mu \mathrm{m}$ (SEM images). Colour online. 
Extant comparative materials

Modern gekkotan and avian eggshells were analysed in more details, as control groups to provide comparative neontological crystallographic data for the two clades suggested to include the potential egg layers (i.e. Gekkota and Theropoda) of Pseudogeckoolithus (see above). Among Gekkota, Gekko gecko and Phelsuma grandis are members of the Gekkonidae (Gamble et al. 2011; Pyron et al. 2013) that lay rigid-shelled eggs, and their eggshells show the typical gekkotan crystallographic arrangement (Choi et al. 2018). Of these, the Gekko gecko eggshell has a nodular ornamentation similar to the dispersituberculate one of Pseudogeckoolithus (Fig. 3F), which led to the gekkotan-affinity interpretation of Pseudogeckoolithus in the past (e.g. Garcia 2000). The gekkotan eggshell materials included in the present study are those analysed in Choi et al. (2018).

We also included in our comparison the eggshells from an emu (Dromaius novaehollandiae) and from a domestic duck (Anas platyrhynchos domesticus), representing a palaeognath and a neognath bird, respectively. The emu eggshell is particularly appropriate for the purpose of this study because it presents ornamentation on its outer surface (Mikhailov 1997b; Grellet-Tinner 2006), which is a very uncommon trait in modern avian eggshells (Hauber 2014). It was found that palaeognath and neognath eggshells have different crystallographic features especially in their misorientation distribution (angular difference between the grains) and $c$-axis alignment (Choi et al. 2019a), and thus the emu and duck eggshells together cover a representative range of modern avian eggshell diversity. For further information, see Choi et al. (2019a). The avian eggshells used in this study were both available commercially.

Last, a crocodylian (Caiman latirostris) eggshell was also analysed to record the crystallography of the ornamentation in non-dinosaurian archosaur eggshell as well, and to compare it with that of Pseudogeckoolithus. The material was provided by Dr Kohei Tanaka (University of Tsukuba) to SC.

\section{Electron backscatter diffraction}

We followed the established methods of EBSD analysis of fossil and modern eggshells and data curation (MorenoAzanza et al. 2013, 2017; Choi et al. 2018, 2019a). The results are presented in inverse pole figure (IPF) maps, lower hemisphere pole figures, grain boundary maps, misorientation histograms, and $d$-value bar charts. Detailed description of the methodology and data curation can be found in Choi et al. (2019b, text S3).

\section{RESULTS}

Crystallography of Pseudogeckoolithus

All European Pseudogeckoolithus eggshells analysed in the present study share several crystallographic features. First, the $c$-axis alignment generally increases from the inner towards the outer part of the shell (Fig. 4), a typical feature of the archosaurian eggshells (Dalbeck \& Cusack 2006; Moreno-Azanza et al. 2013, 2017; Choi et al. 2019a). The shared presence of this pattern in the current sample is also confirmed on multiple of uniform density (MUD) values (see Casella et al. 2018 for explanation) along with the lower hemisphere pole figures (Fig. 4). Second, in all sampled Pseudogeckoolithus shells the nodular ornamentation shows crystallographic architectural continuity with the underlying continuous layer of the eggshell. The large prismatic crystalline domains that form the continuous layer extend into the ornamentation, with two to three domains that contribute to each tubercle (Fig. 4B), implying that the nodular ornamentation was formed by extended eggshell deposition. Third, all European Pseudogeckoolithus shells are characterized by high-angled grain boundaries $\left(>20^{\circ}\right.$ ) (Fig. 5; Choi et al. $2019 a$ ). The misorientation angular distributions are plotted using histograms with neighbour-pair and randompair methods (Fig. 5; Choi et al. 2019b, text S3), and are over $20^{\circ}$ on average with the neighbour-pair method. Detailed description and additional EBSD images of Pseudogeckoolithus from each locality are provided in Choi et al. (2019b, text S4 and fig. S1).

\section{Comparisons with fossil eggshells}

Both hadrosaur and sauropod eggshells are composed of a single layer in which the crystals comprising the eggshell are homogenous throughout its thickness (Grellet-Tinner et al. 2006; Barta et al. 2014; Choi et al. 2019b, fig. S2CF). In eggshells of both clades, low-angle grain boundaries are widespread (Moreno-Azanza et al. 2013, 2016, 2017; Choi et al. 2019b, fig. S2D, F), and most grain boundaries are linear (Grellet-Tinner et al. 2011; Moreno-Azanza et al. 2013, 2017; Eagle et al. 2015). In all of these features, both sauropod and hadrosaur eggshells are markedly different from those of Pseudogeckoolithus.

In contrast, marked microstructural similarities with Pseudogeckoolithus are definitively present in both the troodontid and the enantiornithine eggshells (see Choi et al. 2019b, fig. S2G-J). All of these ootaxa share (1) the existence of an inner mammillary layer and an outer continuous layer, a typical feature of theropod eggshells (Mikhailov 1997a); and (2) rugged grain boundaries in 
A
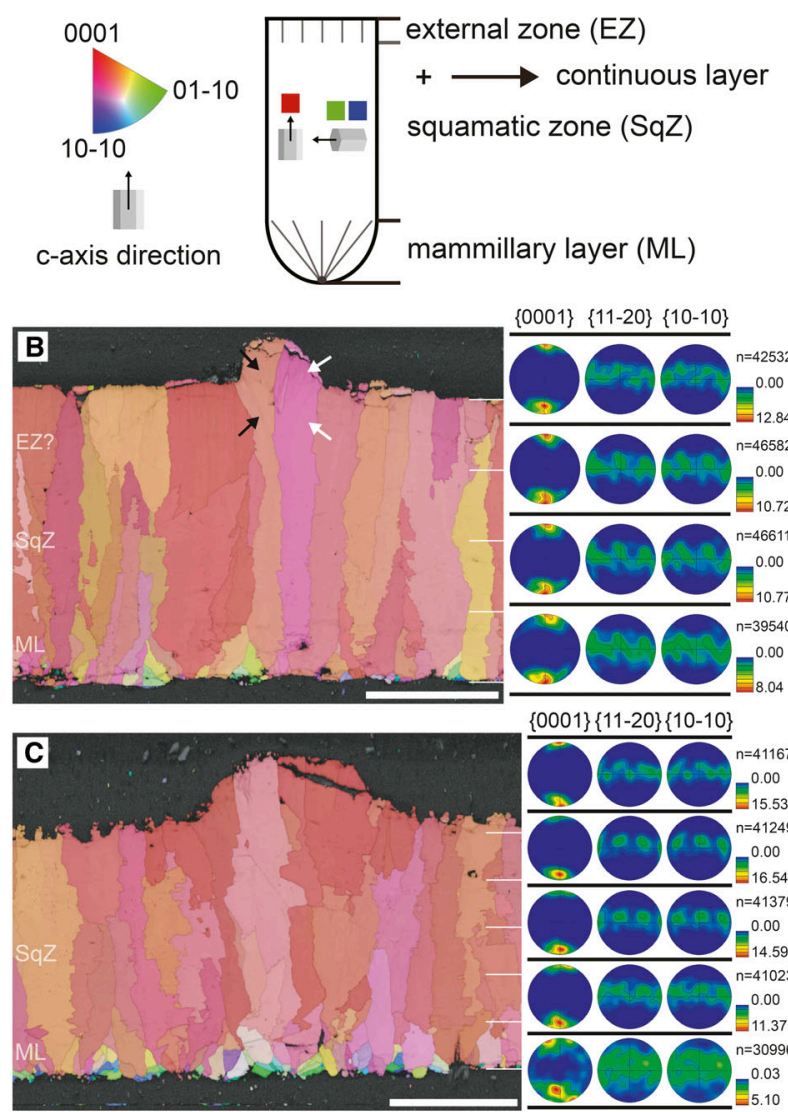
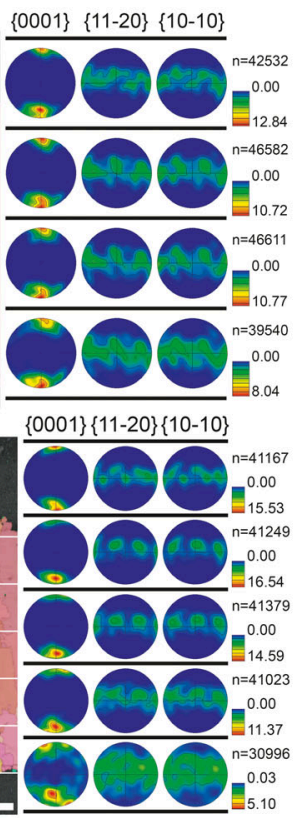
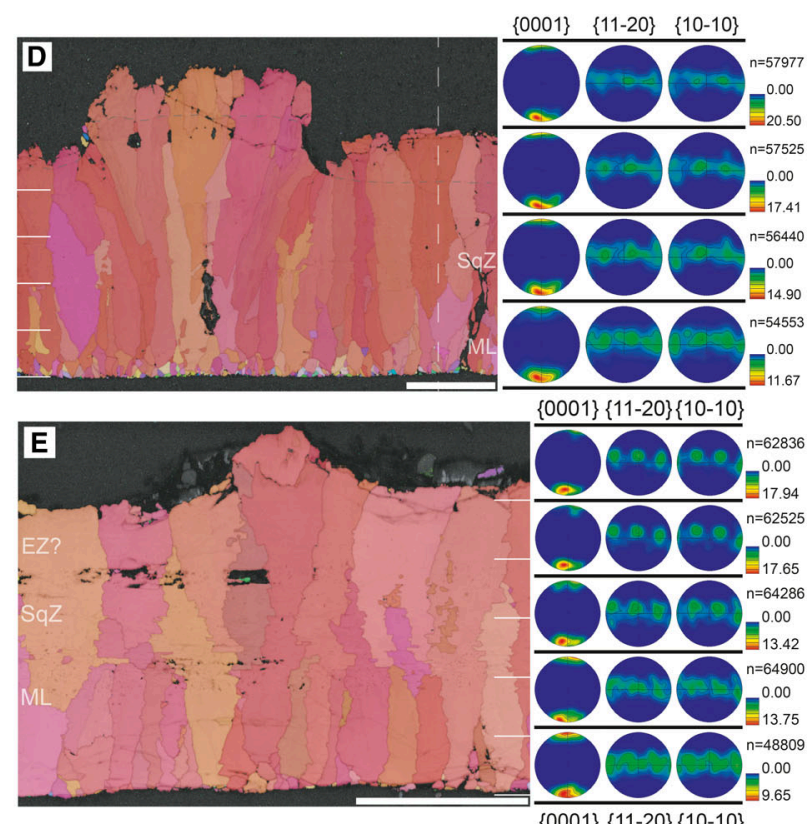

$\{0001\}\{11-20\}\{10-10\}$
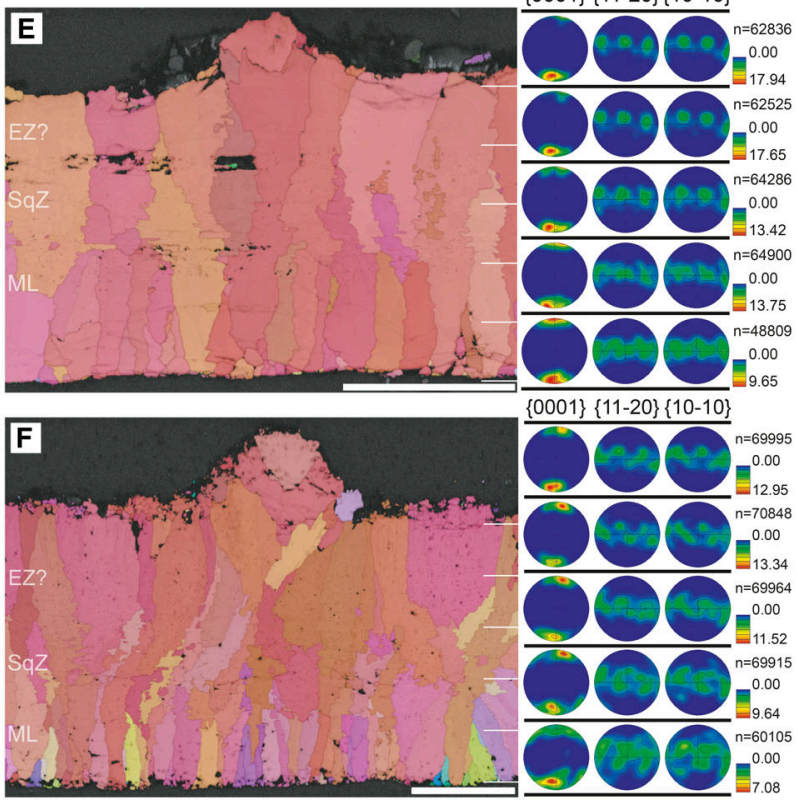

13 FIG. 4. Inverse pole figure (IPF) maps and lower hemisphere pole figures of European Pseudogeckoolithus. A, an interpretation key for IPF maps and abbreviations of eggshell layers. See Choi et al. (2019b, text S3) for details. B, Iharkút (MTM VER 2015. 336c). C, Petrești-Black Lens (LPB [FGGUB] R.2668.2). D, Vălioara-Fântânele (LPB [FGGUB] R.2669.5). E, Pui-Classic (LPB [FGGUB] R.2672.3). F, Blasi 2 (MPZ 2019/580). D, the outer surface of Pseudogeckoolithus (marked by a grey dashed line) is heavily covered with diagenetic calcite overgrowth, which does not reflect genuine biological signal (Choi et al. 2019b, fig. S3A; see also Choi et al. 2019a; Kim et al. 2019). The lower hemisphere pole figures for this specimen were constructed using the grains lying left to the white dashed line in order not to include a crack. In all specimens, the ornamentation is formed through extended shell deposition (black and white arrows in B). Note that in all cases where the ML is preserved, its inner tip is characterized by calcite grains with a horizontally laid $c$ axis, whereas the $c$-axis alignment becomes generally stronger towards the outer eggshell surface, shown by multiple of uniform density (MUD) values on the lower right of the lower hemisphere pole figures (see also Moreno-Azanza et al. 2013, 2017). A MUD of 1 indicates randomly oriented grains; a MUD significantly $>1$ is indicative of a fabric. Scale bars represent $100 \mu \mathrm{m}$.

the squamatic zone, which was suggested to be a diagnostic feature (squamatic ultrastructure) in maniraptoran eggshells (Choi et al. 2019a; see below). Also, the troodontid eggshell and at least some Pseudogeckoolithus specimens share the possible existence of an external zone, which may be diagnosed by the presence of linear grain boundaries, in contrast with the rugged grain boundaries present in the squamatic zone lying below (Choi et al. 2019a; see below). As far as we are aware, there is no known non-theropod dinosaur eggshell that has the aforementioned morphological traits.

\section{Comparison with modern eggshell}

Gekkotan eggs. The crystallographic architecture of modern gekkotan eggshell is unique among amniotes (Choi et al. 2018). The outer quarter of the eggshell is characterized by randomly oriented small calcite grains. The upright $c$-axis alignment (expressed by the intensity of red colour in the IPF map) becomes stronger towards the inner eggshell surface. In addition, the concentration of phosphorus, which is known to function as an inhibitor (as phosphate) of calcite growth (Bachra et al. 1963; Lin 


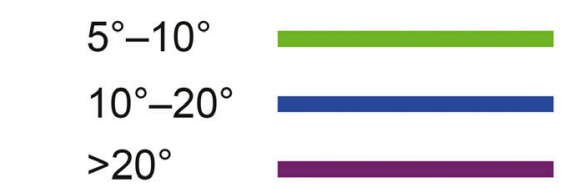

Neighbour-pair misorientation

Random-pair misorientation - Random distribution (theoretical)
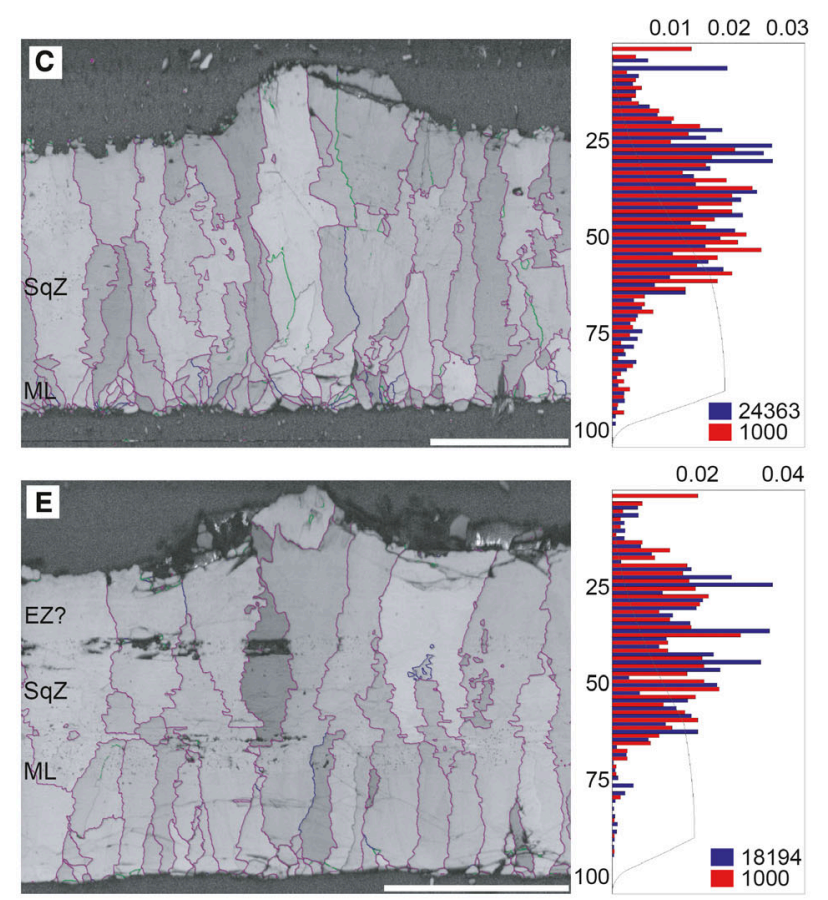
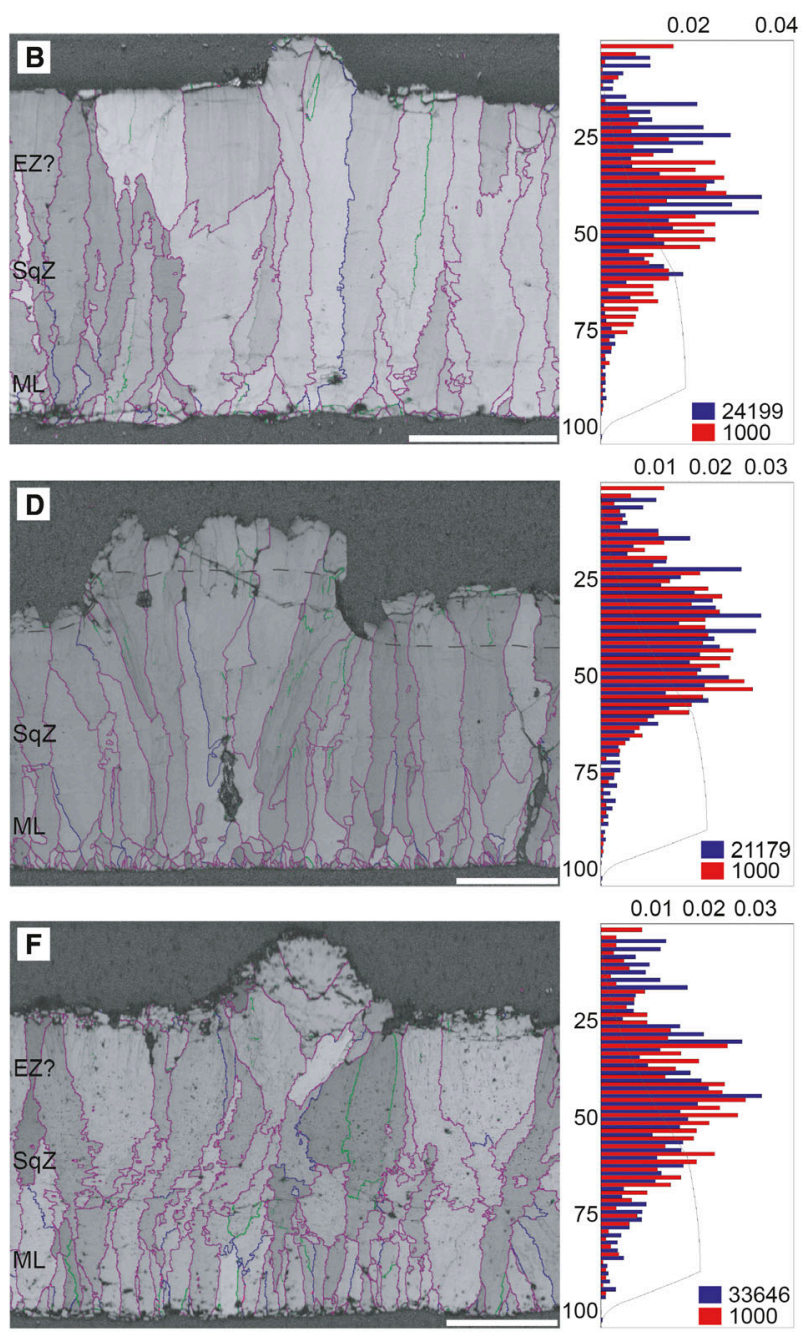

FIG. 5. Grain boundary maps and misorientation histograms of European Pseudogeckoolithus. A, interpretation keys. See Choi et al. (2019b) for details. B, Iharkút (MTM VER 2015. 336c). C, Petrești-Black Lens (LPB [FGGUB] R.2668.2). D, Vălioara-Fântânele (LPB [FGGUB] R.2669.5). E, Pui-Classic (LPB [FGGUB] R.2672.3). F, Blasi 2 (MPZ 2019/580). In all cases, the high-angle grain boundary $\left(>20^{\circ}\right.$; purple line $)$ outnumbers low-angle grain boundary $\left(<20^{\circ}\right.$; blue and green lines). Note rugged grain boundaries in squamatic zone (SqZ) and linear grain boundaries in possible external zone (EZ?), respectively (see Choi et al. 2019b, fig. S4; Choi et al. 2019a). The numbers on the vertical and horizontal axes in the histogram mean degree and frequency of misorientation, respectively. Abbreviation: ML, mammillary layer. Scale bars represent $100 \mu \mathrm{m}$.

\& Singer 2005; Chien et al. 2008), increases towards the inner surface of the eggshell (Choi et al. 2018, figs 7, 8). To the best of our knowledge, these crystallographic and compositional arrangements are observed only in the rigid gekkotan eggshells among amniotes.

The clear-cut crystallographic differences between gekkotan eggshell and Pseudogeckoolithus are also strongly expressed in their dispersituberculate ornamentation. Eggshell ornamentation in Gekko gecko is made up of randomly aligned calcite grains (Fig. 6A), usually with an enigmatic bulbous structure present inside (fig. S9 in Choi et al. 2018). This bulbous structure, however, may not have a crystalline structure given that no Kikuchi pattern (a diffraction pattern used for interpreting the orientation of crystalline material in EBSD analysis) was detected (Fig. 6A; Choi et al. 2018). In contrast, the ornamentation in Pseudogeckoolithus is made up of compact calcite that is crystallographically continuous with the underlying eggshell units (Fig. 4), and does not contain randomly arranged calcite grains. It also lacks the internal bulbous structure seen in eggshell of Gekko gecko.

Avian eggs. In all crystallographic aspects, Pseudogeckoolithus is very similar to theropod (including avian) 
旁
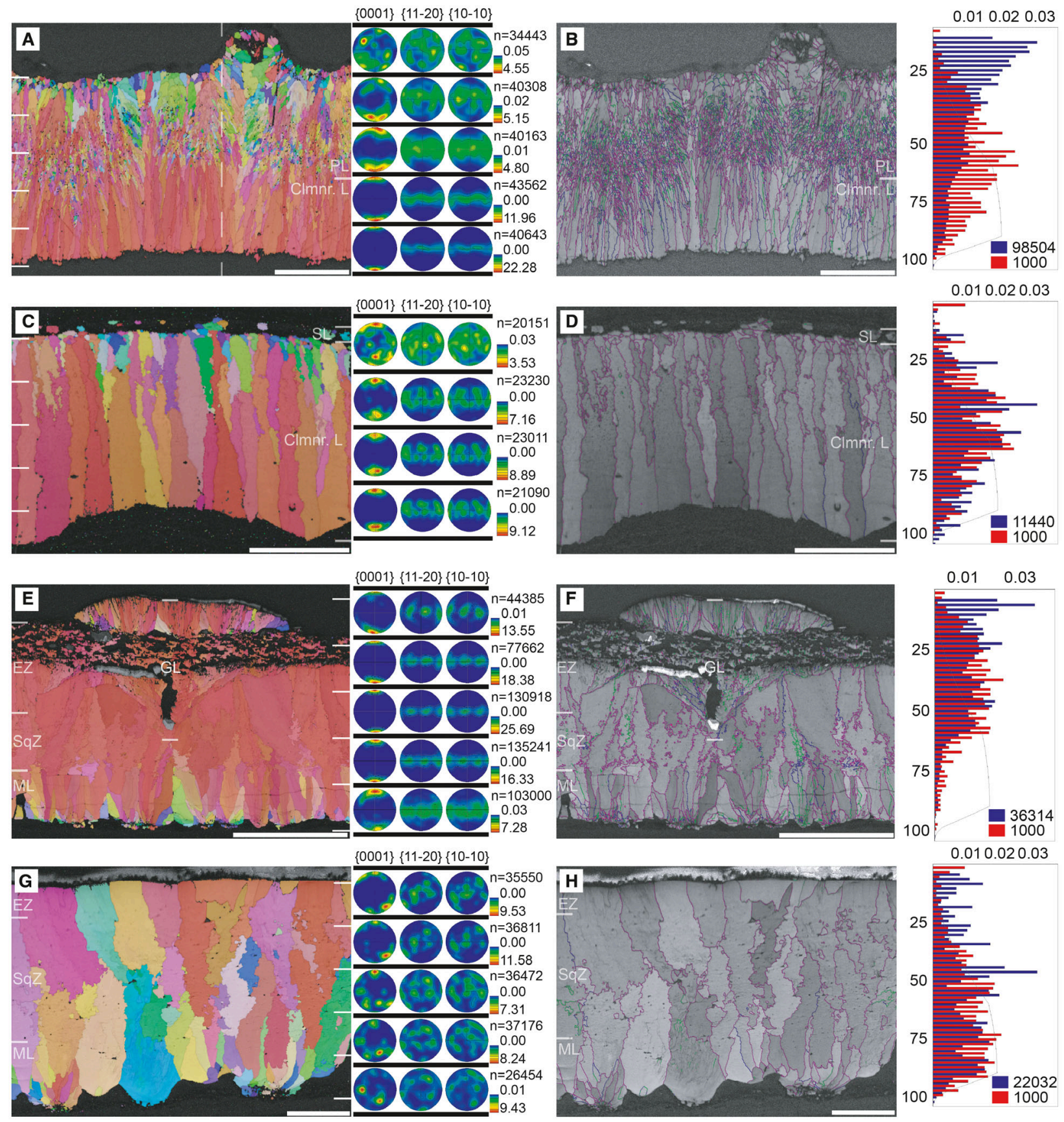

FIG. 6. Eggshell electron backscatter diffraction (EBSD) images from modern representatives of the clades hypothesized to include Pseudogeckoolithus egg layers. A-B, Gekko gecko (Gekkota). C-D, Phelsuma grandis (Gekkota). Gekkotan eggshell terminology follows Choi et al. (2018). E-F, Dromaius novaehollandiae (Aves: Palaeognathae). G-H, Anas platyrhynchos domesticus (Aves: Neognathae). In A, the lower hemisphere pole figures were constructed using the grains lying on the left of the white dashed line so that grains potentially influenced by the ornamentation are not included. In gekkotan eggshells (A, C), $c$-axis alignment becomes higher with vertical orientation towards the inner eggshell surface, the opposite pattern to that seen in Pseudogeckoolithus (Fig. 4) and extant avian eggshells (E, G; Choi et al. 2019a). The ornamentation in Gekko gecko eggshell is composed of randomly oriented calcite grains; that of emu eggshell is composed of wedge-shaped granular layer (GL) initiated in the middle of the squamatic zone (SqZ). Both of them are crystallographically discontinuous with the underlying eggshell. Note the trilaminate structure observed due to grain ruggedness in avian eggshell (F, H), similar to that seen in the Pui-Classic and Blasi 2 Pseudogeckoolithus (Fig. 4E, F). Gekko gecko eggshell has a lowangle-dominant misorientation distribution (B) compared with that of Phelsuma grandis eggshell (D). Key to EBSD interpretation as

20 in Figures 4A, 5A. Abbreviations: Clmnr. L, columnar layer; EZ, external zone; ML, mammillary layer; PL, XXX; SL, XXX. Scale bars represent $100 \mu \mathrm{m}(\mathrm{A}, \mathrm{B}, \mathrm{G}, \mathrm{H}) ; 50 \mu \mathrm{m}(\mathrm{C}, \mathrm{D}) ; 500 \mu \mathrm{m}(\mathrm{E}, \mathrm{F})$. 
eggshell (Fig. 6E-H; Choi et al. 2019b, fig. S2G-J; see Choi et al. 2019a for EBSD analysis of further fossil and extant maniraptoran eggshells). In theropod eggshells, the calcite grains begin to radiate from the eisospherite in the mammillary layer (Fig. 6E-H). When they join inside the continuous layer, calcite grains are usually aligned with their $c$-axis lying perpendicular to the eggshell surface (Fig. 6E, G; see also Dalbeck \& Cusack 2006; MorenoAzanza et al. 2013; Choi et al. 2019a).

In the Dromaius (emu) eggshell there is a granular layer (GL; sensu Mikhailov 1997b) initiated in the middle of the squamatic zone (Fig. 6E) that forms a peculiar, hillock-like ornamentation (sensu Grellet-Tinner 2006). This ornamentation is, however, crystallographically discontinuous with the main eggshell microstructure, thus different from the ornamentation of Pseudogeckoolithus (Fig. 4). The Anas (domestic duck) eggshell is smooth and unornamented, as is the case for almost all modern avian egg-

Except for the presence of a nodular dispersituberculate ornamentation, the crystallographic arrangement of the European Pseudogeckoolithus is especially similar to that of the typical palaeognath eggshell as well as to that of Gobioolithus minor, an enantiornithine ootaxon (Mikhailov 1996; Kurochkin et al. 2013), in that the upright $c$ axis alignment is stronger than that present in neognath eggshells (Fig. 6G; Choi et al. 2019a). More interestingly, Pseudogeckoolithus specimens from two fossil localities surveyed here, Pui-Classic in Romania and Blasi 2 in Spain (Fig. 5E, F) show a marked difference in microstructure compared with the other Pseudogeckoolithus materials studied (Fig. 5B-D), but are similar to the troodontid eggshell (Prismatoolithus levis), in that rugged grain boundaries in the squamatic zone change into linear grain boundaries in the external part of the eggshells; this feature is very clearly seen in the emu eggshell, and is also present in the duck eggshell (Fig. 6E$\mathrm{H})$. The presence of an overlying zone with linear grain boundaries has been postulated as a valid criterion for identifying the external zone (Choi et al. 2019a, b, fig. S4), a well-known trait of modern avian eggshell (Mikhailov 1997b). Although the existence of an external zone must be confirmed by detailed ultrastructural study using scanning electron micrcoscopy, the occurrence of a linear grain boundary near the outer shell surface suggests that an external zone may be also present at least in some Pseudogeckoolithus.

Finally, in several types of avian eggshells examined namely in Gallus (chicken; Cusack et al. 2003), Struthio (ostrich) and Dromaius (Dauphin et al. 2006; Choi et al. $2019 b$, fig. S3B) as well as Pica (Eurasian magpie; Choi et al. 2019b, fig. S3C) eggshells - the concentration of phosphorus increases towards the outer surface, in contrast to the pattern present in gekkotan eggshell. To conclude, the crystallography and chemical composition of the gekkotan eggshells suggest an opposing growth direction compared with that seen in archosaurian eggshells, and is similarly opposite to that present in Pseudogeckoolithus (Fig. 6A, C; Choi et al. 2018).

Crocodylian eggs. Crocodylian eggshell is also characterized by the presence of ornamentation (Schleich \& Kästle 1988), but there is no nodular ornamentation in such an eggshell; instead, most of it is pointed (e.g. Choi et al. $2019 b$, fig. S2A, B) or even more complicated in shape (e.g. Schleich \& Kästle 1988; Cedillo-Leal et al. 2017). The crystals forming crocodylian eggshell are usually wedge shaped (Mikhailov 1997a; Choi et al. 2019b, fig. S2A), thus, it can be easily differentiated from maniraptoran eggshell. Accordingly, the possibility of a crocodylian affinity for Pseudogeckoolithus is minimal.

d-value of diverse sauropsid eggshells

We applied the Kolmogorov-Smirnov test to check for quantitative differences between the neighbour- and random-pair misorientation distributions of Pseudogeckoolithus using $d$-value (Figs 5, 7; Choi et al. 2019a). The higher the $d$-value, the more likely it is that 'neighbouring lattices know about each other in a way that distant (=randomly chosen) lattices do not' (see Wheeler et al. 2001 , p. 113 for details). In addition, to cover the wider range of $d$-values in sauropsid eggshell, we expanded the dataset in Choi et al. $(2019 a, b)$, fig. S4), which consisted only of maniraptoran eggshells.

Except for one Vălioara-Fântânele specimen, all Pseudogeckoolithus have a $d$-value higher than 1.949, meaning that the neighbour- and the random-paired misorientations have a statistically significantly different distribution with probability higher than 0.999 (Fig. 7). The VălioaraFântânele material has a $d$-value of 1.36 , but its neighbour- and random-paired misorientations are still different with a probability higher than 0.95 . The resulting $d$ values were consistent in all European Pseudogeckoolithus specimens investigated with the type 2 distribution typical of maniraptoran eggshells, as documented by Choi et al. (2019a).

We also calculated $d$-values for additional non-Pseudogeckoolithus eggshells analysed in this study as well as those presented elsewhere alongside EBSD data (MorenoAzanza et al. 2013, 2016, 2017; Choi \& Lee 2019). These sample eggshells can be grouped into three categories: (1) maniraptoran eggshells (Dromaius, Reticuloolithus acicularis and Trigonoolithus amoae); (2) non-maniraptoran archosaur eggshells (Caiman latirostris, cf. Maiasaura, Guegoolithus turolensis and Megaloolithus cf. siruguei); and (3) gekkotan eggshells (Gekko gecko and Phelsuma 


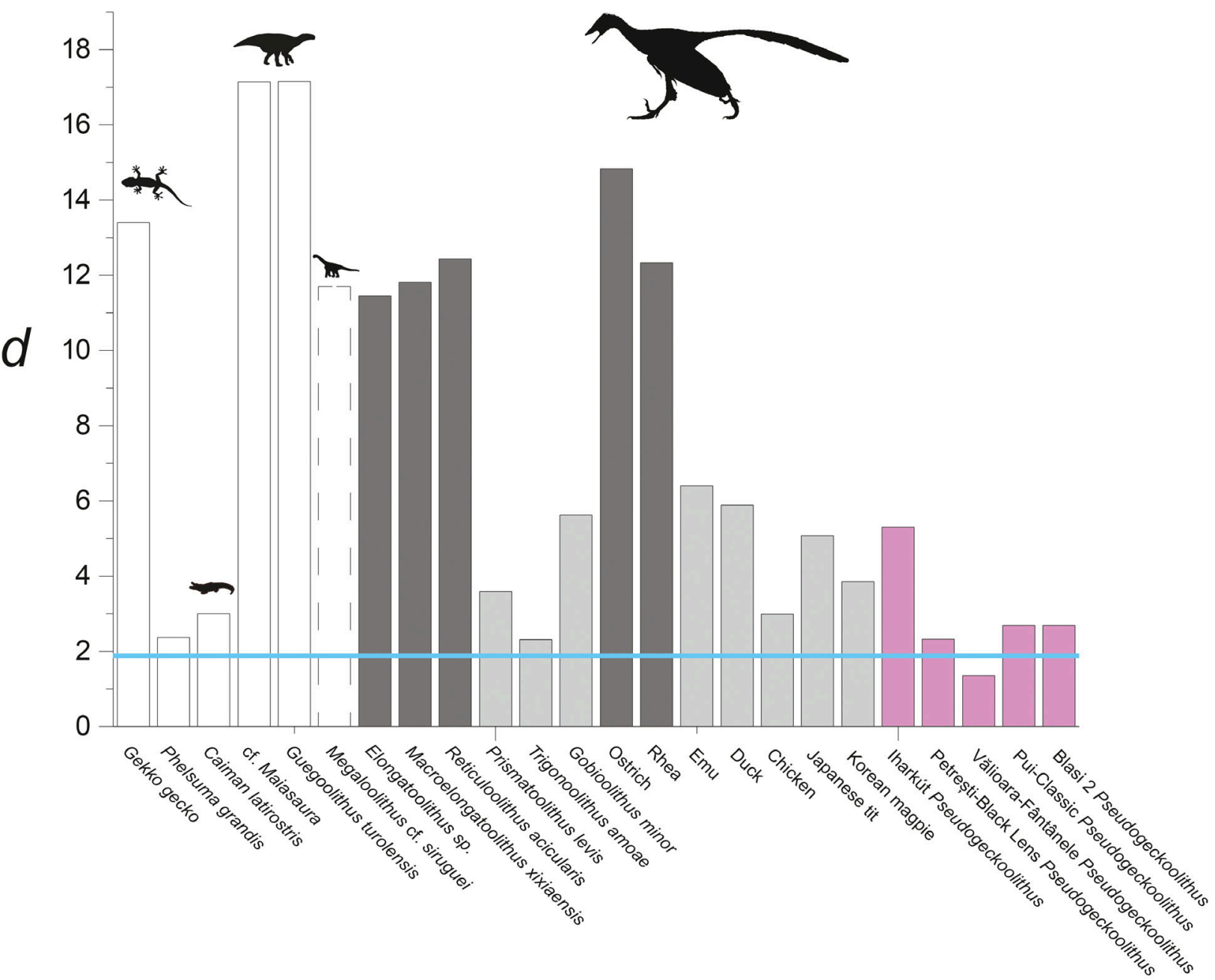

FIG. 7. $d$-value of diverse sauropsid eggshells. Maniraptoran eggshells are coloured and are subdivided into Pseudogeckoolithus (pink), type 1 distribution eggshells (dark grey) and type 2 distribution eggshells (light grey). The sauropod eggshell bar marked by dashed lines was based on taphonomically influenced material (Moreno-Azanza et al. 2016). A blue line marks the $d$-value of 1.949 , above which the neighbour- and the random-paired misorientations have a statistically significantly different distribution with probability higher than 0.999. The source of $d$-values not originally calculated in this study are: Choi et al. (2019a); Choi \& Lee (2019). Silhouettes: Archaeopteryx, Scott Hartman (http://www.phylopic.org); Gekko, Caiman, hadrosaur and sauropod, SC.

grandis). Trigonoolithus showed typical type 2 distribution as anticipated in Choi et al. (2019a). In the case of the Dromaius eggshells, the $d$-value was more similar to the type 2 distribution, although it has the highest $d$-values compared with other type 2 eggshells and still has a significant amount of low-angle grain boundaries under the neighbour-pair method (Fig. 6F), similar to the ostrich and rhea eggshells (Choi et al. 2019a). The ostrich and rhea eggshells used in Choi et al. (2019a) had much higher $d$-values $(>12)$, and thus the case of Dromaius shows that not all palaeognath eggshells have a clear type 1 distribution; instead, some of these demonstrate a transitional state when it comes to misorientation distribution. In contrast, ornithischian eggshells (cf. Maiasaura and Guegoolithus) have the highest $d$-values (>17). The sauropod eggshell (Megaloolithus cf. siruguei) also has a higher $d$-value, but we would like to consider this as a provisional result because it is based on a taphonomically altered sauropod eggshell (Moreno-Azanza et al. 2016) and should be updated with the results derived from better preserved material (e.g. Grellet-Tinner et al. 2011). The Caiman latirostris eggshell has a lower $d$-value, similar to the type 2 distribution of maniraptoran eggshells. Finally, the two gekkotan eggshells show a remarkable contrast in their $d$-values. The $d$-value of the Gekko gecko eggshell was similar to the type 1 distribution of maniraptoran eggshell, while Phelsuma grandis presents the type 2 distribution of maniraptoran eggshell. 


\section{DISCUSSION}

Maniraptoran affinity of Pseudogeckoolithus

The crystallographic features identified on EBSD analysis clearly show that Pseudogeckoolithus is definitively not a squamate eggshell. Crystallographic contrasts documented both in overall eggshell microstructure per se and in ornamentation between the Gekko gecko eggshell and Pseudogeckoolithus document the action of markedly different building pathways that underlay their distinctive architectures. Their apparently highly similar nodular ornamentations are thus truly homoplastic, and, more specifically, convergent sensu Hall (2003; i.e. they represent similarities arising through independent evolution via different developmental pathways). Accordingly, in line with the original interpretation of Vianey-Liaud \& Lopez-Martinez (1997) and, more recently, of Prondvai et al. (2017), but contra Garcia (2000) and Sellés (2012), we firmly establish here the non-gekkotan affinity of the Pseudogeckoolithus material surveyed in this study. Furthermore, we suggest that the previously proposed gekkotan origin of other Late Cretaceous European 'geckoid' eggshell materials, such as that of morphotype geckonoïde of Garcia (2000), should undergo similar scrutiny, given that it shows remarkable external and microstructural similarity to the Pseudogeckoolithus materials studied herein.

Based on the aforementioned features and comparisons, Pseudogeckoolithus can be safely identified as a theropod eggshell. Indeed, Pseudogeckoolithus has at least a two-layered structure made up of a mammillary layer and a squamatic zone (Fig. 4A). This bilaminate structure is absent in sauropod (Grellet-Tinner et al. 2006; MorenoAzanza et al. 2016) and ornithischian (Barta et al. 2014; Moreno-Azanza et al. 2017) eggshells, which are composed of a single layer (mammillae extending up to the outer eggshell surface; see also supplementary text in Stein et al. 2019), whereas it is ubiquitous in known extinct and modern maniraptoran eggshells (Mikhailov 1997a, b; Choi et al. 2019a). Also, hadrosaur and sauropod eggshells have abundant low-angle grain boundaries, whereas such are rarely observed in Pseudogeckoolithus. All these observations eliminate any potential hadrosaur or sauropod affinity for Pseudogeckoolithus, not to mention the extreme thinness of Pseudogeckoolithus, compared with the eggshells typical for the other two clades.

In contrast, admittedly, non-maniraptoran theropod eggs are as yet poorly known: the only definite cases are represented by eggs ascribed to the megalosaurid Torvosaurus (Carrano et al. 2012) and to the allosauroid Lourinhanosaurus (Malafaia et al. 2017), both from the Upper Jurassic of Portugal (Araújo et al. 2013; Ribeiro et al. 2014). The eggshell of Torvosaurus has only a single layer (Araújo et al. 2013; Ribeiro et al. 2014), whereas that of Lourinhanosaurus is two-layered (Mateus et al. 1997; Ribeiro et al. 2014), similar to the typical maniraptoran eggshell. However, whether the two-layered structure of the Lourinhanosaurus eggshell has a similar crystallographic make-up to those of the maniraptorans is as yet unknown, and should be clarified (Choi \& Lee 2019).

To conclude, within Theropoda, Pseudogeckoolithus can be assigned to a maniraptoran egg-layer on the basis of (1) a two-layered structure, with the presence of a mammillary layer and a continuous layer, character shared with all maniraptoran taxa (Mikhailov 1997a) and with the allosauroid Lourinhanosaurus (Mateus et al. 1997; Ribeiro et al. 2014); (2) an angusticanaliculate pore system (Prondvai et al. 2017), shared with most maniraptorans including Aves (Mikhailov 1997a); and (3) the possible existence of an external zone, a character widespread within avian eggshells (Mikhailov 1997b) and which is also present in some derived maniraptorans eggshells (e.g. Trigonoolithus amoae, Triprismatoolithus stephensi and Prismatoolithus levis; Varricchio \& Jackson 2004, 2010; Jackson \& Varricchio 2010; Moreno-Azanza et al. 2014b). Moreover, its greatly reduced thickness, suggestive of [a] small-sized theropod egg-layer[s] (Prondvai et al. 2017), may further support its maniraptoran affinity, given that most Late Cretaceous European maniraptorans (including non-avian paravians; the theropods of unknown affinity Richardoestesia and Euronychodon; as well as enantiornithine and ornithurine birds; Csiki-Sava et al. 2015) are characterized by small body size. Meanwhile, it is worth noting that all known non-maniraptoran Late Cretaceous theropods from Europe (abelisauroids, basal tetanurans) were medium- to largesized animals (Csiki-Sava et al. 2015). Such a mutually exclusive body size distribution among the Late Cretaceous theropods of Europe minimizes the possibility that Pseudogeckoolithus is an ootaxon of a medium- to largesized non-maniraptoran theropod, considering the known positive correlations between adult body mass and egg size in extant Aves (Juang et al. 2017), and that between egg mass (hence, size) and eggshell thickness (Ar et al. 1979).

Nevertheless, further specimens, including more complete eggs (or fortuitous discoveries such as in ovo embryos or gravid females), are needed to firmly establish the affinity of Pseudogeckoolithus, given that assigning a particular ootaxon to a certain clade can be erroneous in the absence of an embryo preserved in ovo (see discussion in Choi \& Lee 2019). Embryo in ovo specimens would also narrow the assignment of the Pseudogeckoolithus eggs to one of the maniraptoran groups that were present in 
Europe at the end of the Cretaceous. It is worth noting, nonetheless, that eggs and eggshells from the Maastrichtian of Romania reported to co-occur with skeletal remains of (and thus referred to) taxonomically indeterminate enantiornithines (Dyke et al. 2012) differ markedly in their ornamentation pattern (Fernández et al. 2019) from the typical dispersituberculate ornamentation of Pseudogeckoolithus.

\section{EBSD, an adequate tool to identify true fossil gekkotan eggshell}

Our EBSD analyses clearly show that Pseudogeckoolithus is not a gekkotan-related ootaxon; instead, it can be safely identified as belonging to a maniraptoran theropod group. In future studies, our approach can be extended and it should be applied to other putative fossil squamate eggshells (Choi et al. 2019b, table S1; text S5) in order to rigorously determine their accurate crystallographic arrangement and thereby assess the most likely phylogenetic affinity. Equally importantly, there are further documented examples of rigid squamate eggshell producers, both extant and fossil, such as the diplodactylid gekkotan Eurydactylodes (it may have acquired a rigid eggshell independently from other gekkotan families; Kratochvil \& Frynta 2006), some Dibamidae (Choi et al. 2018), and certain fossil Anguimorpha (Fernandez et al. 2015). It is not yet known whether the peculiar and very characteristic crystallographic arrangement of the rigid gecko eggshell (Choi et al. 2018) is autapomorphic, or whether it is more widespread among the rigid eggshell-producing squamates. Therefore, fossil rigid eggshells that are found without an associated embryo in ovo, and are probably not of archosauromorph origin, currently can be identified neither as gekkotan, nor as non-gekkotan squamate eggshells with certainty. Hence, for a comprehensive understanding of rigid eggshell evolution in Squamata, and in amniotes in general, as well as for correct taxonomic identification of fossil squamate eggshells, additional modern and fossil samples should also be analysed using EBSD.

Eggshell ornamentation in extant megapode birds, Gekko gecko and fossil maniraptorans

In extant sauropsids, gekkotan and crocodylian eggshells regularly exhibit ornamentation (Schleich \& Kästle 1988; Marzola et al. 2015; Cedillo-Leal et al. 2017; Choi et al. 2018), while this is mostly absent in avian eggshells. Rare exceptions to the latter pattern are the nodular eggshell ornamentation of megapodes (Galliformes, Neognathae; Grellet-Tinner et al. 2017) and the modest hillock-like ornamentation found in cassowary and emu (Casuariidae, Palaeognathae; Mikhailov 1997b; Zelenitsky \& Modesto 2003; Grellet-Tinner 2006; Lawver \& Boyd 2018). Although many Cretaceous and Palaeogene avian eggshells also lacked ornamentation (Mikhailov 1996; Grellet-Tinner \& Dyke 2005; Jackson et al. 2013; Varricchio \& Barta 2015; Fernández et al. 2019), this condition was probably not always the dominant phenotype throughout avian evolutionary history. For example, the Palaeogene Metoolithus nebraskensis (Jackson et al. 2013) and $M$. jacksonae (Lawver \& Boyd 2018), as well as Ornitholithus (Donaire \& López-Martínez 2009; Angst et al. 2015) are all recognized as ornamented avian eggshells. Furthermore, ornamentation characterizes the eggshells of diverse Cretaceous non-avian maniraptorans (e.g. Deinonychus eggshell, Elongatoolithidae, Nipponoolithus, Reticuloolithus, Trigonoolithus and Triprismatoolithus; Mikhailov 1997a; Grellet-Tinner \& Makovicky 2006; Jackson \& Varricchio 2010; Moreno-Azanza et al. 2014b; Tanaka et al. 2016; Choi \& Lee 2019), members of the dinosaur clade giving rise to birds. Thus, ornamentation is highly likely to be a plesiomorphic character of the maniraptoran eggshell that disappeared in some extinct and most modern avian taxa (Lawver \& Boyd 2018).

The maniraptoran affinity of Pseudogeckoolithus verified in the present study raises the question of why extremely similar dispersituberculate ornamentation exists in eggshells of such distantly related clades as Maniraptora and Squamata. Eggshells of extant megapode birds and Gekko gecko possess ornamentation with discrete and sparse nodes (Grellet-Tinner et al. 2017; Choi et al. 2018), and a gecko-like dispersituberculate ornamentation is now also documented in the extinct maniraptoran Pseudogeckoolithus. Even though the nodular eggshell ornamentation seen in the modern maniraptoran megapodes is somewhat different in its gross morphology from that of the extinct maniraptoran Pseudogeckoolithus, megapode and Pseudogeckoolithus eggshells share similar basic crystallographic features. In the megapodes Alectura lathami and Leipoa ocellata the eggshell ornamentation is formed through extended shell deposition (Grellet-Tinner et al. 2017), just as we document here in Pseudogeckoolithus (Fig. 4). This type of crystallographic make-up was also reported in oviraptorosaur eggshells (Elongatoolithus, Macroelongatoolithus; Choi et al. 2019a), although the ornamentation pattern itself is usually different in its morphology, being linear (Mikhailov 1997a) rather than nodular as in Pseudogeckoolithus (but also note that Macroelongatoolithus possesses dispersituberculate ornamentation as well; Simon et al. 2019). In addition, ornamentation of the anguimorph eggshell from the Lower Cretaceous of Thailand (Fernandez et al. 2015) also shows morphological similarity with that of the megapode eggshell. It is the only definitive case of squamate eggshell 
known in the fossil record (identification supported by associated in ovo embryos), meaning that rigid eggshell and its nodular ornamentation are not unique traits of gecko eggshells within squamates, but may have been more widespread among their fossil representatives.

The reason for the presence of ornamentation in sauropsid eggshell is a neglected topic in vertebrate palaeontology, except for one speculation (Grellet-Tinner et al. 2017). Although the nesting microenvironment of Gekko gecko has never been studied, there are several studies on the nesting microenvironment of megapodes. Megapode eggs, which are buried in various substrates and are incubated by environmental heat instead of body heat (Booth \& Thompson 1991), have a comparatively thinner shell than eggs laid by similar-sized avian taxa that use body heat in contact incubation. This relative thinness of the megapode eggshell was suggested to represent an adaptation that enhances gas exchange in the peculiar covered nesting environment of megapodes (Booth \& Thompson 1991; Harris et al. 2014; Grellet-Tinner et al. 2017; but see Birchard \& Deeming 2009 for an opposing view). Among maniraptoran-related ootaxa, the European Pseudogeckoolithus eggshells are also characterized by their remarkable thinness (Table 1; Choi et al. 2019b, text S4; Prondvai et al. 2017).

Given that the megapode and the G. gecko eggshell ornamentation represent outlier characters within their own clades (Aves and Gekkota, respectively), their similar gross morphology despite marked differences in underlying crystallographic make-up (resulting from different formational pathways, as shown by EBSD; see Choi et al. $2019 b$, text S6 for our view on the eggshell as an end-product of a complex eggshell calcite growth mechanism) may suggest an adaptive significance of this discrete nodular pattern of ornamentation, possibly driven by some kind of similar selection pressure in maniraptorans and gekkotans. Likewise, given that megapodes are derived neornithine maniraptorans (Prum et al. 2015), their eggshell ornamentation, which is similar only to that of the distantly related Cretaceous maniraptoran Pseudo-

28 geckoolithusis, is most likely to be a homoplastic feature that may have been caused by similar nesting microenvironmental settings in megapodes and Pseudogeckoolithus (see below). For these reasons, the eggshells of G. gecko and/or megapodes might be functionally comparable with, and informative for the interpretation of, the Santonian-Maastrichtian dispersituberculate theropod eggshells, including Pseudogeckoolithus (Table 1). Nevertheless, an alternative explanation, namely that this similarity in ornamentation may be only a random outcome of genetic drift and thus represents a non-adaptive retention or novel development of a functionless (and harmless) character in either clade (Gould \& Lewontin 1979; Losos 2011), should not be overlooked.
We suggest that neontological experimental data should be gathered by ornithologists and/or herpetologists from the aforementioned extant taxa to shed light on the reason(s), if any, behind the presence of eggshell ornamentation, a feature that represented a dominant phenotypical trend for Mesozoic maniraptoran eggshells (Table 1). Experimental approaches to test its possible role(s), such as those implemented by Cedillo-Leal et al. (2017) for crocodylian eggshells, as well as detailed observations on the nesting microenvironments of megapodes and Gekko gecko, compared with those of other avian and gekkotan taxa, could help to clarify the evolutionary significance of eggshell ornamentation. This in turn might offer further insights into the reproductive palaeobiology of other dinosaurian and squamate clades with ornamented eggshells (Mikhailov 1997a; Fernandez et al. 2015), and may also give hints as to why eggshell ornamentation has disappeared in the majority of modern birds (Hauber 2014; Lawver \& Boyd 2018).

\section{Misorientation pattern in sauropsid eggshells}

The presence of a crystallographic dichotomy (i.e. type 1 and 2 misorientation distributions) within extinct and modern maniraptoran eggshells was first reported in Choi et al. (2019a). The enlarged dataset used in the present study provides further insights into the crystallographic features of diverse sauropsid eggshells.

First, in Choi et al. (2019a), palaeognaths were represented only by ostrich and rhea, which both have definitive type 1 distribution. However, the current study documents that the eggshell of the palaeognath Dromaius has a more type 2-like distribution (at least in its $d$ value), similar to that of the neognath eggshells (Fig. 7), a finding that is further supported by the rarity of lowangled grain boundary in the emu eggshell (Fig. 6F). This implies that the distribution of type 1 and type 2 crystallographic patterns in avian eggshells is more complicated than that presented in Choi et al. (2019a, fig. 10), and thus a phylogenetically controlled sample derived from a wide range of avian clades, including palaeognaths and neognaths, should be analysed to better understand the evolutionary pattern.

Second, two ornithopod and sauropod eggshells analysed in this study yielded high $d$-values (we would refrain from using the term 'type 1' distribution for non-maniraptoran eggshells because it was initially coined only for maniraptoran eggshells, and furthermore, the question of whether the high $d$-value seen in ornithopod and sauropod eggshells and the type 1 distribution of maniraptoran eggshells were both inherited from their common ancestor is far from being answered). Although the $d$-value obtained for the sauropod eggshell in the present study 


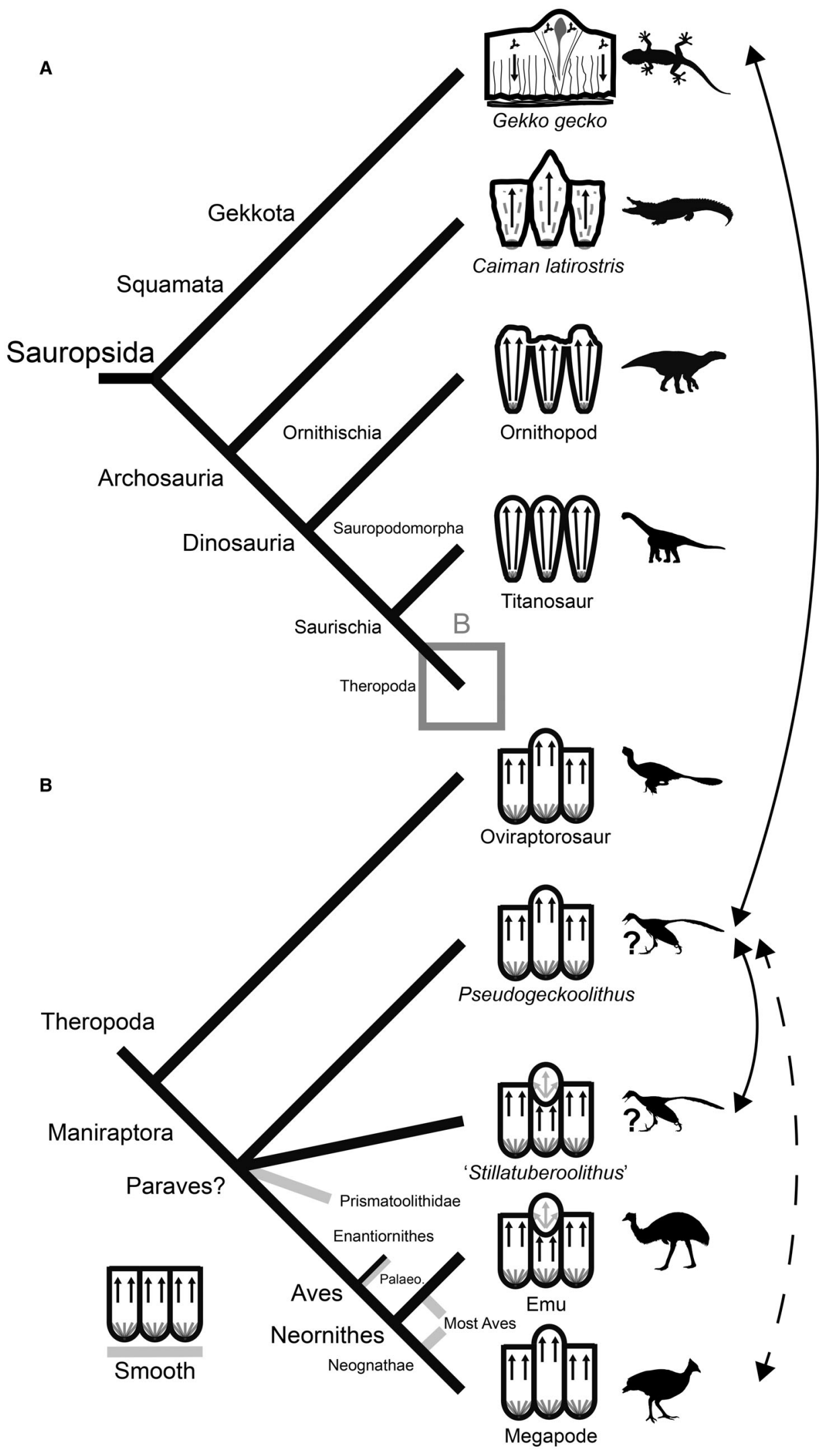


should be double-checked using better preserved eggshells, the results - if upheld -imply that, in general, higher $d$-values (such as those found in the maniraptoran type 1 distribution) may be more widespread within Dinosauria than the lower $d$-values, and that the lower $d$ values may be correlated with the unique reproductive strategy of maniraptoran dinosaurs (i.e. contact incubation; Varricchio \& Jackson 2016; Choi et al. 2019a and references therein). Admittedly, this inference should be further checked using a more comprehensive sample of sauropod and ornithischian dinosaur eggshell material because (as documented in the case of the Dromaius eggshell, above) the phylogenetic distribution of high and low $d$-values may be rather complicated and can only be clarified through an extensive investigation. Nevertheless, the present results provide a first glimpse into the $d$-value distribution of non-maniraptoran dinosaur eggshells.

Finally, even though only two gekkotan species were analysed in this respect, surprisingly they show contrasting $d$-values. Similar to the case of maniraptoran eggshells reported by Choi et al. (2019a), a crystallographic dichotomy may also be present in gekkotan (or squamate, in general) eggshells, reinforcing the need for future comparative investigations into the microstructure and crystallography of a diverse array of squamate eggshells (see above).

\section{Detecting homoplasy in eggshell evolution}

Ornamentation morphology has been widely used as a criterion to classify ootaxa at the oofamily level (e.g. Mikhailov et al. 1996). However, the present results imply that ornamentation (similarly to other characters such as egg shape, shell unit shape and pore system; Mikhailov 1997a) is also prone to homoplasy (Fig. 8).

Pseudogeckoolithus, 'Stillatuberoolithus', Macroelongatoolithus, a fossil anguimorph eggshell, as well as eggshell of Gekko gecko, megapodes, cassowary and emu, are all characterized by surface ornamentation although the morphology varies (Figs 4-6, 8; Mikhailov 1997b; Zelenitsky \& Modesto 2003; Grellet-Tinner 2006; Fernandez et al. 2015; Grellet-Tinner et al. 2017; Oser 2018; Choi et al. 2018, 2019a). We have shown that the similar-looking dispersituberculate eggshell ornamentation of Pseudogeckoolithus and Gekko gecko represents a clear case of convergent evolution. Meanwhile, the presence of uniform crystallography of the eggshell ornamentation (formed via extended deposition of the calcite grains) in the more closely related maniraptorans Pseudogeckoolithus, oviraptorosaurs (e.g. Macroelongatoolithus) and megapodes (Fig. 8; Grellet-Tinner et al. 2017; Choi et al. 2019a) documents the emergence of a common pathway of ornamentation building in maniraptoran eggshells, despite their different overall (or gross) morphology. Such a pathway appears to be a widely used template in ornamentation building in sauropsid eggshells (Fig. 8). In the case of 'Stillatuberoolithus' and of the extant Dromaius eggshells, however, the surface ornamentation is not crystallographically continuous with the underlying eggshell (Fig. 6E, F; Oser 2018). Instead, the appearance of ornamentation is 'programmed' crystallographically in the middle of the squamatic zone (Fig. 8), a feature so distinctive that the ornamentation was actually interpreted as a fourth layer in the case of the Dromaius eggshell by Grellet-Tinner (2006).

In summary, there are at least three different ways of producing dispersituberculate ornamentation in sauropsid eggshells: the gecko style; the Pseudogeckoolithus style; and the 'Stillatuberoolithus' style; which can be unambiguously detected on EBSD analysis. The occurrence and distribution of these three different crystallographic patterns of ornamentation building in sauropsid eggshells document clear cases of homoplasy (Fig. 8). Considering that the eggs of almost all modern avian taxa have lost ornamentation (see above), the similarity recorded between Pseudogeckoolithus and the megapode eggshell is probably homoplastic unless an alternative scenario is true: that a relict ornamentation of a non-avian maniraptoran eggshell is uniquely retained by an avian clade, the megapodes.

FIG. 8. Three types of ornamentation construction pathway in sauropsid eggshells and possible homoplasies. A, schematic crystallography of non-maniraptoran sauropsid eggshells used in this study. B, schematic crystallography of maniraptoran eggshells. In almost all sauropsid eggshells including Pseudogeckoolithus, ornamentation is crystallographically continuous with underlying eggshell, suggesting extended deposition (Fig. 4; Moreno-Azanza et al. 2013; Grellet-Tinner et al. 2017; Choi et al. 2019a). In contrast, ornamentation of 'Stillatuberoolithus' and modern emu eggshells is initiated in the middle of the eggshell with wedge-shaped structures (Fig. 6E,F; Oser 2018), implying another pathway of ornamentation construction. In Gekko gecko eggshell, ornamentation is composed of randomly oriented calcite grains and contains non-crystalline material inside (Choi et al. 2018). The three different crystallographical patterns of ornamentation indicate homoplastic ornamentation evolution. Phylogenetic occurrences of smooth maniraptoran eggshells are indicated with grey branches. Instances of morphological similarity that can be interpreted as clear convergent evolution and possibly other types of homoplasy are marked with solid and dashed arrows, respectively. Note that only convergent evolution is clearly detectable on crystallographic electron backscatter diffraction analysis. Silhouettes are attributable to (http://www.phylopic.org): Emily Willoughby (Citipati); Scott Hartman (Archaeopteryx), Darren Naish and Michael Keesey (Dromaius). Silhouettes of Gekko, Caiman, hadrosaur, sauropod and Megapodius, SD. 
In the case of the ornamentation of 'Stillatuberoolithus', it is underlain by a profoundly different generative mechanism from that seen in the typical two- or three-layered maniraptoran eggshells (Zelenitsky \& Modesto 2003; Grellet-Tinner 2006; Lawver \& Boyd 2018; Oser 2018), one also typified by Pseudogeckoolithus as we have shown. Accordingly, 'Stillatuberoolithus' documents the emergence of a second ornamentation-building pathway in maniraptoran eggshell evolution. The presence of these two widely divergent building patterns shows that even if the dispersituberculate ornamentation of 'Stillatuberoolithus' is extremely similar to that of Pseudogeckoolithus, this gross similarity clearly represents a case of convergent morphology. Similar instances of independent evolutionary acquisition and disappearance of closely comparable character states were also suggested in another eggshell component, the cuticle (D'Alba et al. 2016). In fact, calcified eggshell thickening per se has most likely evolved in diverse amniote clades, even within Dinosauria, several times independently (Stein et al. 2019).

The susceptibility of ornamentation to homoplasy has important implications for eggshell parataxonomy. It was argued that many eggshell characters are highly modular (sensu Klingenberg 2008) and are driven by mosaic evolution resulting in independent character combinations (Varricchio \& Jackson 2004; Jackson et al. 2013; Lawver \& Boyd 2018). The morphology of ornamentation is diverse in dinosaurian eggshells (Mikhailov 1997a), but we document here that even markedly different microstructure and crystallography can result in (or generate) almost identical gross morphologies, as shown in the cases of 'Stillatuberoolithus' and Pseudogeckoolithus (Fig. 8).

For these reasons, we suggest that both morphology and its underlying crystallography (which can be used as a proxy of the eggshell calcite growth mechanism; see Choi et al. 2019b, text S6) have to be considered together before using superficial similarities as diagnostic eggshell characters implying homology in parataxonomical assessments. 30 However, there is still difficulty even in such mechanismbased identifications. Although EBSD can be used to identify definitive cases of convergent evolution in eggshell formation, characterized by different underlying mechanisms on crystallography, the reverse does not necessarily hold true: detecting the presence of a uniform mechanism does not always guarantee homologous origin of a feature, especially if the taxa of interest are only distantly related (see also Hall 2003; Shubin et al. 2009 for a more complicated case called 'deep homology'). Considering the limited number of possible ways to build ornamentation or even a hard eggshell per se (Stein et al. 2019), we may expect to find identical crystallography expressed in distantly related clades that nevertheless acquired (or reinvented) their common traits independently. So far, none of the known approaches in eggshell research has provided a way to safely separate true homology from homoplasy if a character shared by several taxa has both similar morphology and a similar underlying mechanism. Such difficulties notwithstanding, in the effort to establish monophyletic groups in eggshell parataxonomy, clearly convergent characters (such as the ornamentation in G. gecko eggshells and Pseudogeckoolithus, as demonstrated in this study) have to be identified, and handled accordingly (for further criticism on current practices in parataxonomy see also Zelenitsky et al. 2002; Varricchio \& Jackson 2004; Grellet-Tinner 2006; but see Mikhailov 2014 for a contrary opinion). Only such rigorous approaches to phylogenetic analysis will make parataxonomic classification of the diverse fossil eggshell record a biologically and evolutionarily meaningful effort.

\section{SYSTEMATIC PALAEONTOLOGY}

\author{
Oofamily PRISMATOOLITHIDAE Hirsch, 1994 emend. \\ Moreno-Azanza et al. $2014 b$ \\ Oogenus PSEUDOGECKOOLITHUS Vianey-Liaud \& Lopez- \\ Martinez 1997
}

Type oospecies. Pseudogeckoolithus nodosus Vianey-Liaud \& Lopez-Martinez 1997.

Emended diagnosis. After Vianey-Liaud \& Garcia (2003). Thin prismatic eggshell $(200-350 \mu \mathrm{m}$ including ornamentation), outer surface with dispersituberculate ornamentation, formed by irregular nodes, which are tubercle- or crater-like in shape. Wide pore openings at the top of some nodes. Egg shape and size unknown.

Age and distribution. Late Late Cretaceous (late Santonian - late Maastrichtian); upper Santonian-Maastrichtian of Europe (France, Hungary, Romania and Spain) and Maastrichtian of Africa (Morocco).

Remarks. The type material of Pseudogeckoolithus, supposedly housed at Universidad Complutense de Madrid, is currently not accessible because it was lost after the death of Professor López-Martínez. Future studies should consider collecting new material at Fontllonga 6 locality (Lleida, Spain) in order to establish a neotype for the oogenus.

\section{Pseudogeckoolithus cf. nodosus Figures $3 \mathrm{C}, \mathrm{E} ; 4 \mathrm{C}, \mathrm{E} ; 5 \mathrm{C}$, E}

Holotype and type locality. FLL6-14, a single eggshell fragment from the early Maastrichtian Fontllonga 6 locality, Lleida, Spain (Vianey-Liaud \& Lopez-Martinez 1997). The holotype material is lost. 
Distribution and age. Vălioara-Fântânele, Densuș-Ciula Formation, Romania; early Maastrichtian; Blasi 2, Arén Formation, Spain; late Maastrichtian.

Description. Isolated eggshell fragments, $350 \mu \mathrm{m}$ in thickness including ornamentation ( $280 \mu \mathrm{m}$ excluding ornamentation). Outer surface with dispersituberculate ornamentation, with sparse nodes, sometimes with pore openings on the top of the nodes. In radial section, the eggshells show dinosaur prismatic morphotype, with a mammillary : continuous layer ratio of $1 / 3$ to $1 / 9$.

Remarks. We choose to use open nomenclature because the samples are too scarce, and we were not able to directly compare them with the holotype. Nevertheless, the proximity of Blasi 2 site to the roughly contemporaneous Fontllonga 6 type locality strongly supports attribution of Pseudogeckoolithus material from here to this oospecies.

\section{Pseudogeckoolithus aff. tirboulensis Figures 3A, B, D; 4A, B, D; 5A, B, D}

31 Holotype and type locality. $\mathrm{ACH} 2-330$, a thin section of an eggshell fragment; the Maastrichtian locality Achlouj 2, Morocco (Vianey-Liaud \& Garcia 2003).

Distribution and age. Iharkút SZ-6 and SZ-7-8, Csehbánya Formation, Hungary; late Santonian; PetreștiBlack Lens, Sebeș Formation, Romania, latest Campanian; Pui-Classic, Pui Beds, Romania, early late Maastrichtian.

Description. Eggshells are very thin (200-250 $\mu \mathrm{m}$ including ornamentation; $130-220 \mu \mathrm{m}$ excluding ornamentation). Outer surfaces with dispersituberculate ornamentation, but somewhat more densely ornamented than Pseudogeckoolithus cf. nodosus. Pore openings on the top of some of the nodes. In radial section, they present dinosaur prismatic morphotype, with a mammillary : continuous layer ratio of 1:1 to $1: 6$.

Remarks. Eggshells referred in this study to Pseudogeckoolithus aff. tirboulensis resemble those described by Vianey-Liaud \& Garcia (2003) from the Upper Cretaceous of Morocco in thickness, ornamentation and general histological structure. Nevertheless, they differ from the type material of Pseudogeckoolithus tirboulensis in the mammillary : continuous layer ratio, which in the African material is much higher (1:2). Accordingly, the Pseudogeckoolithus material from Hungary (see also Prondvai et al. 2017), and most probably that described here from the Romanian localities of Petrești-Black Lens and Pui-Classic, may represent a new oospecies of Pseudogeckoolithus.

\section{CONCLUSIONS}

The contentious affinity of enigmatic 'geckoid' eggshells from Upper Cretaceous deposits of Europe was resolved: they were identified as theropod eggshells using a crystallographic approach (EBSD). This study provides a template case to enable potential squamate eggshells, a poorly investigated category in vertebrate palaeontology, to be rigorously tested and positively identified using EBSD. More importantly, we show that among nodular sauropsid eggshells, there are at least three different mechanisms that generate ornamentation (as shown on crystallography). Until recently, when a certain eggshell phenotype (=character) was found to share similar morphology across several taxa, these were usually treated as homologies, and were coded into the character-taxon matrix accordingly. However, similar morphology does not always represent homology, and may be homoplastic instead. Using a crystallographic approach, such hidden homoplasies (especially convergence) can be detected in the case of fossil and modern eggshells. Hence, before identifying a particular morphological similarity as a potential homology, its underlying mechanism should also be considered, in order to avoid treating homoplasy as homology. Finally, detailed crystallographic investigation of a more extensive sample of dinosaur (including Aves) and squamate eggshells is necessary, given that the present results point to a more complicated evolutionary history of the sauropsid eggshell crystallography (and also that of its production mechanisms) than was previously thought, with significant implications for the reconstruction of the reproductive (palaeo)biology of amniotes.

Acknowledgements. Seokyoung Han (Seoul National University) helped SC in constructing lower hemisphere pole figures. We also thank Gerald Grellet-Tinner (CRILAR/CONICET, Orcas Island Historical Museum), Mark Hauber (University of Illinois at Urbana-Champaign), Juan Daza (Sam Houston State University) and Rebecca Harris (Arizona State University) for confirming the contents in their papers and a book. Kohei Tanaka (University of Tsukuba) and Noe-Heon Kim (SNU) helped us with the literature search. For help with specimens and information, we thank the following colleagues: Attila Ösi (Eötvös Loránd University) for collecting the Hungarian fossil eggshells; the Hungarian National History Museum and its chief curator for Paleontology and Geology, Alfréd Dulai, for access to fossil eggshells; Mátyás Vremir (Transylvanian Museum Society) for offering access to the Petrești-Black Lens eggshells, and sharing information concerning the Transylvanian enantiornithine eggshells; Ștefan Vasile (University of Bucharest) for helping to collect the Romanian specimens; José Ignacio Canudo (Director, Museo de Ciencias Naturales de la Universidad de Zaragoza) for providing access to Spanish specimens; Delphine Angst (University of Bristol) for contributing French thin-shelled eggshell 
specimens useful in comparisons; Eric Buffetaut (CNRS) for sharing information and providing references on French 'geckoid' eggshell occurrences; and Hiroki Echizenya (Hokkaido University Museum) and Kohei Tanaka for providing modern crocodylian eggshells. We appreciate Daniel Lawver (Stony Brook University), an anonymous referee and editors Imran Rahman and Sally Thomas for their constructive comments that helped to improve the previous version of this MS. Silhouettes in Figures 7 and 8 are attributed to Emily Willoughby (Citipati, CC-BY-SA 3.0), Scott Hartman (Archaeopteryx, CC0 1.0), and Darren Naish and T. Michael Keesey (Dromaius, CC-BY 3.0). This work was supported by National Research Foundation of Korea (grant number 2019R1A2B5B02070240) to YNL. MMA is supported by Fundação para a Ciência e a Tecnologia (project number PTDC/CTA-PAL/31656/2017 and postdoctoral grant number SFRH/BPD/113130/2015). EP was supported by the Bijzonders Onderzoeksfonds (BOF) - Universiteit Gent (grant number 01P12815); MTA-MTM-ELTE Research Group for Paleontology (grant number MTA-MTM-ELTE Paleo Contribution 33 No. XXXX).

\section{AUTHOR CONTRIBUTIONS}

SC and EP conceived the study. SC, EP and YNL designed the study. MMA, ZCS and EP provided fossil material and SC and YNL provided modern eggshells. SC performed analysis and collected data. All authors interpreted results. SC, MMA, ZCS and EP wrote the manuscript. All authors gave final approval for publication.

\section{DATA ARCHIVING STATEMENT}

Data for this study are available in the Dryad Digital Repository: https://doi.org/10.5061/dryad.v75qf08

Editor. Imran Rahman

\section{REFERENCES}

AMIOT, R., WANG, X., WANG, S., LÉCUYER, C., MAZIN, J.-M., MO, J., FLANDROIS, J.-P., FOUREL, F., WANG, X., XU, X., ZHANG, Z. and ZHOU, Z. 2017. $\delta^{18} \mathrm{O}$-derived incubation temperatures of oviraptorosaur eggs. Palaeontology, 60, 633-647.

ANGST, D., AMIOT, R., BUFFETAUT, E., FOUREL, F., MARTINEAU, F., LAZZERINI, N. and LÉCUYER, C. 2015. Diet and climatic context of giant birds inferred from $\delta^{13} \mathrm{C}_{\mathrm{c}}$ and $\delta^{18} \mathrm{O}_{\mathrm{c}}$ values of Late Palaeocene and Early Eocene eggshells from southern France. Palaeogeography, Palaeoclimatology, Palaeoecology, 435, 210-221.

ANTONESCU, E., LUPU, D. and LUPU, M. 1983. Correlation palinologique du Crétacé terminal du sud-est des Monts Metaliferi et des Depressions de Hațeg de Rusca Montană. Anuarul Institutului de Geologie și Geofizică, 59, 71-77.
AR, A., RAHN, H. and PAGANELLI, C. V. 1979. The avian egg: mass and strength. Condor, 81, 331-337.

ARAÚJO, R., CASTANHINHA, R., MARTINS, R. M. S., MATEUS, O., HENDRICKX, C., BECKMANN, F., SCHELL, N. and ALVES, L. C. 2013. Filling the gaps of dinosaur eggshell phylogeny: Late Jurassic Theropod clutch with embryos from Portugal. Scientific Reports, 3, 1924.

ARDÈVOL, L., KLIMOWITZ, J., MALAGÓN, J. and NAGTEGAAL, P. J. C. 2000. Depositional sequence response to foreland deformation in the Upper Cretaceous of the southern Pyrenees, Spain. AAPG Bulletin, 84, 566-587.

BACHRA, B. N., TRAUTZ, O. R. and SIMON, S. L. 1963. Precipitation of calcium carbonates and phosphates. I. Spontaneous precipitation of calcium carbonates and phosphates under physiological conditions. Archives of Biochemistry \& Biophysics, 103, 124-138.

BALANOFF, A. M., NORELl, M. A., GRELLET-TINNER, G. and LEWIN, M. R. 2008. Digital preparation of a probable neoceratopsian preserved within an egg, with comments on microstructural anatomy of ornithischian eggshells. Naturwissenschaften, 95, 493-500.

BARTA, D. E., BRUNDRIDGE, K. M., CROGHAN, J. A., JACKSON, F. D., VARRICCHIO, D. J., JIN, X. and POUST, A. W. 2014. Eggs and clutches of the Spheroolithidae from the Cretaceous Tiantai basin, Zhejiang Province, China. Historical Biology, 26, 183-194.

BENTON, M. J., CSIKI-SAVA, Z., GRIGORESCU, D., REDELSTORFF, R., SANDER, P. M., STEIN, K. and WEISHAMPEL, D. B. 2010. Dinosaurs and the island rule: the dwarfed dinosaurs from Hațeg Basin. Palaeogeography, Palaeoclimatology, Palaeoecology, 293, 438-454.

BIRCHARD, G. F. and DEEMING, D. C. 2009. Avian eggshell thickness: scaling and maximum body mass in birds. Journal of Zoology, 279, 95-101.

BLAIN, H.-A., CANUDO, J.-I., CUENCA-BESCÓS, G. and LÓPEZ-MARTÍNEZ, N. 2010. Amphibians and squamate reptiles from the latest Maastrichtian (Upper Cretaceous) of Blasi 2 (Huesca, Spain). Cretaceous Research, 31, 433-446.

BODOR, E. R. and BARANYI, V. 2012. Palynomorphs of the Normapolles group and related plant mesofossils from the Iharkút vertebrate site, Bakony Mountains (Hungary). Central European Geology, 55, 259-292.

BOJAR, A.-V., HALAS, S., BOJAR, H.-P., GRIGORESCU, D. and VASILE, S. 2011. Upper Cretaceous volcanoclastic deposits from the Hațeg Basin, south Carpathians (Romania): K-Ar ages and intrabasinal correlation. Geochronometria, 38, 182-188.

BOOTH, D. T. and THOMPSON, M. B. 1991. A comparison of reptilian eggs with those of megapode birds. 325-344. In DEEMING, D. C. and FERGUSON, M. W. J. (eds). Egg incubation: Its effects on embryonic development in birds and reptiles. Cambridge University Press, $448 \mathrm{pp}$.

BOTFALVAI, G., ÖSI, A. and MINDSZENTY, A. 2015. Taphonomic and paleoecologic investigations of the Late Cretaceous (Santonian) Iharkút vertebrate assemblage (Bakony Mts, Northwestern Hungary). Palaeogeography, Palaeoclimatology, Palaeoecology, 417, 379-405. 
- HAAS, J., BODOR, E. R., MINDSZENTY, A. and ÖSI, A. 2016. Facies architecture and palaeoenvironmental implications of the upper Cretaceous (Santonian) Csehbánya formation at the Iharkút vertebrate locality (Bakony Mountains, Northwestern Hungary). Palaeogeography, Palaeoclimatology, Palaeoecology, 441, 659-678.

- CSIKI-SAVA, Z., GRIGORESCU, D. and VASILE, Ş. 2017. Taphonomical and palaeoecological investigation of the Late Cretaceous (Maastrichtian) Tuștea vertebrate assemblage (Romania; Hațeg Basin): insights into a unique dinosaur nesting locality. Palaeogeography, Palaeoclimatology, Palaeoecology, 468, 228-262.

BRAY, E. S. 1999. Eggs and eggshells from the Upper Cretaceous North Horn Formation, central Utah. 361-375. In GILlETTE, D. D. (ed.) Vertebrate paleontology in Utah. Utah Geological Survey, Salt Lake City.

CANUDO, J. I. 2018. The collection of type fossils of the Natural Science Museum of the University of Zaragoza (Spain). Geoheritage, 10, 385-392.

- OMS, O., VIlA, B., GAlOBART, À., FONDEVILLA, V., PUÉRTOLAS-PASCUAL, E., SELLÉS, A. G., CRUZADO-CABALLERO, P., DINARÈS-TURELL, J., VICENS, E., CASTANERA, D., COMPANY, J., BURREL, L., ESTRADA, R., MARMI, J. and BLANCO, A. 2016. The upper Maastrichtian dinosaur fossil record from the southern Pyrenees and its contribution to the topic of the Cretaceous-Palaeogene mass extinction event. Cretaceous Research, 57, 540-551.

CARRANO, M. T., BENSON, R. B. J. and SAMPSON, S. D. 2012. The phylogeny of tetanurae (Dinosauria: Theropoda). Journal of Systematic Palaeontology, 10, 211-300.

CASELLA, L. A., GRIESSHABER, E., SIMONET RODA, M., ZIEGler, A., MAVROMATIS, V., HENKEL, D., LAUDIEN, J., HÄUSSERMANN, V., NEUSER, R. D., ANGIOLINI, L., DIETZEL, M., EISENHAUER, A., IMMENHAUSER, A., BRAND, U. and SCHMAHL, W. W. 2018. Micro- and nanostructures reflect the degree of diagenetic alteration in modern and fossil brachiopod shell calcite: a multi-analytical screening approach (CL, FE-SEM, AFM, EBSD). Palaeogeography, Palaeoclimatology, Palaeoecology, 502, 13-30.

CEDILLO-LEAL, C., SIMONCINI, M. S., LEIVA, P. M. L., LARRIERA, A., LANG, J. W. and PIÑA, C. 2017. Eggshell structure in Caiman latirostris eggs improves embryo survival during nest inundation. Proceedings of the Royal Society B, 284, 20162675.

CHASSAGNE-MANOUKIAN, M., HADDOUMI, H., CAPPETTA, H., CHARRIÈRE, A., FEIST, M., TABUCE, R. and VIANEY-LIAUD, M. 2013. Dating the "red beds" of the Eastern Moroccan High Plateaus: evidence from late Late Cretaceous charophytes and dinosaur eggshells. Geobios, 46, 371-379.

CHIEN, Y.-C., HINCKE, M. T., VALI, H. and McKEE, M. D. 2008. Ultrastructural matrix-mineral relationships in avian eggshell, and effects of osteopontin on calcite growth in vitro. Journal of Structural Biology, 163, 84-99.

CHOI, S. and LEE, Y.-N. 2019. Possible Late Cretaceous dromaeosaurid eggshells from South Korea: a new insight into dromaeosaurid oology. Cretaceous Research, 103, 104167.

— HAN, S., KIM, N.-H. and LEE, Y.-N. 2018. A comparative study of eggshells of Gekkota with morphological, chemical compositional and crystallographic approaches and its evolutionary implications. PLoS One, 13, e0199496.

and LEE Y.-N. 2019a. Electron backscatter diffraction (EBSD) analysis of maniraptoran eggshells with important implications for microstructural and taphonomic interpretations. Palaeontology, 62, 777-803.

MORENO-AZANZA, M., CSIKI-SAVA, Z., PRONDVAI, E. and LEE, Y.-N. 2019b. Data from: Comparative crystallography suggests maniraptoran theropod affinities for latest Cretaceous European 'geckoid' eggshell. Dryad Digital Repository, https://doi.org/10.5061/dryad.v75qf08 CODREA, V., SMITH, T., DiCA, P., FOliE, A., GARCIA, G., GODEFROIT, P. and VAN ITTERBEECK, J. 2002. Dinosaur egg nests, mammals and other vertebrates from a new Maastrichtian site of the Hațeg Basin (Romania). Comptes Rendus Palevol, 1, 173-180.

- VREMIR, M., JIPA, C., GODEFROIT, P., CSIKI, Z., SMITH, T. and FĂRCAŞ, C. 2010a. More than just Nopcsa's Transylvanian dinosaurs: a look outside the Hațeg Basin. Palaeogeography, Palaeoclimatology, Palaeoecology, 293, 391-405.

- BARBU, O. and JIPA-MURZEA, C. 2010b. Upper Cretaceous (Maastrichtian) land vertebrate diversity in Alba district (Romania). Bulletin of the Geological Society of Greece, 43, 594-601.

_ JIPA-MURZEA, C., CSIKI-SAVA, Z. and BARBU, O. 2010c. Maastrichtian dinosaurs in SW Transylvania (Romania). 69-74. In CHRISTOFIDES, G., KANTIRANIS, N., KOSTOPOUlOS, D. S. and CHATZIPETROS, A. A. (eds). Proceedings of the 19th Congress of the Carpathian-Balkan Geological Association, Thessaloniki.

COJAN, I. and MOREAU, M.-G. 2006. Correlation of terrestrial climatic fluctuations with global signals during the Upper Cretaceous-Danian in a compressive setting (Provence, France). Journal of Sedimentary Research, 76, 589-604.

CORRAL, J.-C., PUEYO, E. L., BERRETEAGA, A., RODRÍGUEZ-PINTÓ, A., SÁNCHEZ, E. and PEREDA-SUBERBIOLA, X. 2016. Magnetostratigraphy and lithostratigraphy of the Laño vertebrate-site: implications in the uppermost Cretaceous chronostratigraphy of the BasqueCantabrian Region. Cretaceous Research, 57, 473-489.

COUSIN, R. 1997. Nouvelle découverte de fragments de coquilles d'oeufs à structure ornithoïde, dans les sédiments du Maastrichtien continental de Rennes-le-Château (Aude). Bulletin Trimestrielle de la Société Géologique de Normandie et Amis du Muséum du Havre, 84, 13-15.

CSIKI-SAVA, Z., IONESCU, A. and GRIGORESCU, D. 2008. The Budurone microvertebrate site from the Maastrichtian of the Hațeg Basin: flora, fauna, taphonomy and paleoenvironment. Acta Palaeontologica Romaniae, 6, 49-66.

- BUFFETAUT, E., ŐSI, A., PEREDA-SUBERBIOLA, X. and BRUSATTE, S. L. 2015. Island life in the Cretaceous: faunal composition, biogeography, evolution, and extinction of land-living vertebrates on the Late Cretaceous European archipelago. ZooKeys, 469, 1-161. 
VREMIR, M., VASIlE, Ș., BRUSATTE, S. L., DYKE, G., NAISH, D., NORELL, M. A. and TOTOIANU, R. 2016. The East Side Story: the Transylvanian latest Cretaceous continental vertebrate record and its implications for understanding Cretaceous-Paleogene boundary events. Cretaceous Research, 57, 662-698.

CUSACK, M., FRASER, A. C. and STACHEL, T. 2003. Magnesium and phosphorus distribution in the avian eggshell. Comparative Biochemistry and Physiology Part B, 134, 63-69.

D'ALBA, L., MAIA, R., HAUBER, M. E. and SHAWKEY, M. D. 2016. The evolution of eggshell cuticle in relation to nesting ecology. Proceedings of the Royal Society B, 283, 20160687.

DALBECK, P. and CUSACK, M. 2006. Crystallography (electron backscatter diffraction) and chemistry (electron probe microanalysis) of the avian eggshell. Crystal Growth \& Design, 6, 2558-2562.

DAUPHIN, Y., CUIF, J.-P., SALOMÉ, M., SUSINI, J. and WILLIAMS, C. T. 2006. Microstructure and chemical composition of giant avian eggshells. Analytical \& Bioanalytical Chemistry, 386, 1761-1771.

DAZA, J. D., BAUER, A. M. and SNIVELY, E. D. 2014. On the fossil record of the Gekkota. The Anatomical Record, 297, 433-462.

DONAIRE, M. and LÓPEZ-MARTÍNEZ, N. 2009. Porosity of Late Paleocene Ornitholithus eggshells (Tremp Fm, southcentral Pyrenees, Spain): palaeoclimatic implications. Palaeogeography, Palaeoclimatology, Palaeoecology, 279, 147-159.

DYKE, G., VREMIR, M., KAISER, G. and NAISH, D. 2012. A drowned Mesozoic bird breeding colony from the Late Cretaceous of Transylvania. Naturwissenschaften, 99, 435-442.

EAGLE, R. A., ENRIQUEZ, M., GRELLET-TINNER, G., PÉREZ-HUERTA, A., HU, D., TÜTKEN, T., MONTANARI, S., LOYD, S. J., RAMIREZ, P., TRIPATI, A. K., KOHN, M. J., CERLING, T. E., CHIAPPE, L. M. and EILER, J. M. 2015. Isotopic ordering in eggshells reflects body temperatures and suggests differing thermophysiology in two Cretaceous dinosaurs. Nature Communications, 6, 8296.

FERNANDEZ, V., BUFFETAUT, E., SUTEETHORN, V., RAGE, J.-C., TAFFOREAU, P. and KUNDRÁT, M. 2015. Evidence of egg diversity in squamate evolution from Cretaceous anguimorph embryos. PLoS One, 10, e0128610.

FERNÁNDEZ, M. S., WANG, X., VREMIR, M., LAURENT, C., NAISH, D., KAISER, G. and DYKE, G. 2019. A mixed vertebrate eggshell assemblage from the Transylvanian Late Cretaceous. Scientific Reports, 9, 1944.

FONDEVILLA, V., DINARÈS-TURELL, J. and OMS, O. 2016. The chronostratigraphic framework of the South-Pyrenean Maastrichtian succession reappraised: implications for basin development and end-Cretaceous dinosaur faunal turnover. Sedimentary Geology, 337, 55-68.

— RIERA, V., VILA, B., SELLÉS, A. G., DINARÈSTURELL, J., VICENS, E., GAETE, R., OMS, O. and GALOBART, À. 2019. Chronostratigraphic synthesis of the latest Cretaceous dinosaur turnover in south-western Europe. Earth-Science Reviews, 191, 168-189.

GAMBle, T., BAUER, A. M., COLli, G. R., GREENBAUM, E., JACKMAN, T. R., VITT, L. J. and SIMONS,
A. M. 2011. Coming to America: multiple origins of New World geckos. Journal of Evolutionary Biology, 24, 231-244.

GARCIA, G. 2000. Diversité des coquilles “minces" d'oeufs fossils du Crétacé supérieur du Sud de la France. Geobios, 33, 113-126. [in French, English abstract]

— and VIANEY-LIAUD, M. 2001. Dinosaur eggshells as biochronological markers in Upper Cretaceous continental deposits. Palaeogeography, Palaeoclimatology, Palaeoecology, 169, 153-164.

- FEIST, M., CABOT, A., VALENTIN, X. and VIANEY-LIAUD, M. 2000. Les oeufs de dinosaures du Crétacé supérieur du bassin de Villeveyrac-Mèze (Hérault, France): description d'une nouvelle ooespèce de Prismatoolithus. Bulletin de la Société Géologique de France, 171, 283-289. [in French, English abstract]

SMith, T., FOlie, A., GODEFroit, P., VAN ITTERBEECK, J. and CODREA, V. 2002. Parataxonomic classification of eggshells from Pui in the Hațeg Basin (Romania). 13. In GRIGORESCU, D. and CSIKI, Z. (eds). 7th European Workshop on Vertebrate Palaeontology, Abstracts Volume and Excursions Field Guide. Sibiu, Romania.

— TABUCE, R., CAPPETTA, H., MARANDAT, B., BENTALEB, I., BENABDALLAH, A. and VIANEYLIAUD, M. 2003. First record of dinosaur eggshells and teeth from the north-west African Maastrichtian (Morocco). Palaeovertebrata, 32, 59-69.

GOULD, S. J. and LEWONTIN, R. C. 1979. The spandrels of San Marco and the Panglossian paradigm: a critique of the adaptationist programme. Proceedings of the Royal Society B, 205, 581-598.

GRELLET-TINNER, G. 2006. Phylogenetic interpretation of eggs and eggshells: implications for phylogeny of Palaeognathae. Alcheringa, 30, 141-182.

— and DYKE, G. 2005. The eggshell of the Eocene bird Lithornis. Acta Palaeontologica Polonica, 50, 831-835.

- and MAKOVICKY, P. 2006. A possible egg of the dromaeosaur Deinonychus antirrhopus: phylogenetic and biological implications. Canadian Journal of Earth Sciences, 43, 705-719.

- ChIAPPE, L., NORELL, M. and BOTTJER, D. 2006. Dinosaur eggs and nesting behaviours: a paleobiological investigation. Palaeogeography, Palaeoclimatology, Palaeoecology, 232, 294-321.

— SIM, C. M., KIM, D. H., TRIMBY, P., HIGA, A., AN, S. L., OH, H. S., KIM, T. J. and KARDJILOV, N. 2011. Description of the first lithostrotian titanosaur embryo in ovo with Neutron characterization and implications for lithostrotian Aptian migration and dispersion. Gondwana Research, 20, 621-629.

- Codrea, V., Folie, A., HigA, A. and SMith, T. 2012. First evidence of reproductive adaptation to "island effect" of a dwarf Cretaceous Romanian Titanosaur, with embryonic integument in ovo. PLoS One, 7, e32051.

- LINDSAY, S. and THOMPSON, M. B. 2017. The biomechanical, chemical and physiological adaptations of the eggs of two Australian megapodes to their nesting strategies and their implications for extinct titanosaur dinosaurs. Journal of Microscopy, 267, 237-249. 
GRIGORESCU, D., VENCZEL, M., CSIKI-SAVA, Z. and LIMBEREA, R. 1999. New Latest Cretaceous microvertebrate fossil assemblage from the Hațeg Basin (Romania). Geologie en Mijnbouw, 78, 301-314.

- GARCIA, G., CSIKI-SAVA, Z., CODREA, V. and BOJAR, A.-V. 2010. Uppermost Cretaceous megaloolithid eggs from the Hațeg Basin, Romania, associated with hadrosaur hatchlings: search for explanation. Palaeogeography, Palaeoclimatology, Palaeoecology, 293, 360-374.

HAAS, J. E. 1983. Senonian cycle in the Transdanubian Central Range. Acta Geologica Hungarica, 26, 21-40.

— JOCHA-EDELÉNYI, E. and CSÁSZÁR, G. 1992. Upper Cretaceous coal deposits in Hungary. 245-262. In McCABE, P. J. and PARRICH, J. T. (eds). Controls on the distribution and quality of Cretaceous coals. Geological Society of America Special Paper 267, Boulder, CO.

HALL, B. K. 2003. Descent with modification: the unity underlying homology and homoplasy as seen through an analysis of development and evolution. Biological Reviews, 78, 409-433.

HARRIS, R. B., BIRKS, S. M. and LEACHÉ, A. D. 2014. Incubator birds: biogeographical origins and evolution of underground nesting in megapodes (Galliformes: Megapodiidae). Journal of Biogeography, 41, 2045-2056.

HAUBER, M. E. 2014. The book of eggs: A lifesize guide to the eggs of six hundred of the world's bird species. University of Chicago Press, 656 pp.

HIRSCH, K. F. 1994. Upper Jurassic eggshells from the Western Interior of North America. 137-150. In CARPENTER, K., HIRSCH, K. F. and HORNER, J. R. (eds). Dinosaur eggs and babies. Cambridge University Press.

— 1996. Parataxonomic classification of fossil chelonian and gecko eggs. Journal of Vertebrate Paleontology, 16, $752-762$.

— and QUINN, B. 1990. Eggs and eggshell fragments from the Upper Cretaceous Two Medicine Formation of Montana. Journal of Vertebrate Paleontology, 10, 491-511.

JACKSON, F. D. and VARRICCHIO, D. J. 2010. Fossil eggs and eggshell from the lowermost Two Medicine Formation of western Montana, Sevenmile Hill Locality. Journal of Vertebrate Paleontology, 30, 1142-1156.

_ 2016. Fossil egg and eggshells from the Upper Cretaceous Hell Creek Formation, Montana. Journal of Vertebrate Paleontology, 36, e1185432.

— - and CORSINI J. A. 2013. Avian eggs from the Eocene Willwood and Chadron formations of Wyoming and Nebraska. Journal of Vertebrate Paleontology, 33, $1190-1201$.

- SCHAFF, R. J., VARRICCHIO, D. J. and SCHMITT, J. G. 2015. A theropod nesting trace with eggs from the Upper Cretaceous (Campanian) Two Medicine Formation of Montana. Palaios, 30, 362-375.

JUANG, J.-Y., CHEN, P.-Y., YANG, D.-C., WU, S.-P., YEN, A. and HSIEH, H.-I. 2017. The avian egg exhibits general allometric invariances in mechanical design. Scientific Reports, 7, 14205.

KEROURIO, P. 1982. Un nouveau type de coquille d'oeuf présumé dinosaurien dans le Campanien et le Maestrichtien continental de Provence. Palaeovertebrata, 12, 141-147.
KHOSLA, A. and SAHNI, A. 1995. Parataxonomic classification of Late Cretaceous dinosaur eggshells from India. Journal of the Palaeontological Society of India, 40, 87-102.

KIM, N.-H., CHOI, S., KIM, S. and LEE, Y.-N. 2019. A new faveoloolithid oogenus from the Wido Volcanics (Upper Cretaceous), South Korea and a new insight into the oofamily Faveoloolithidae. Cretaceous Research, 100, 145-163.

KLINGENBERG, C. P. 2008. Morphological integration and developmental modularity. Annual Review of Ecology, Evolution, \& Systematics, 39, 115-132.

KRATOCHVIL, L. and FRYNTA, D. 2006. Egg shape and size allometry in geckos (Squamata: Gekkota), lizards with contrasting eggshell structure: why lay spherical eggs? Journal of Zoological Systematics \& Evolutionary Research, 44, 217-222.

KUROCHKIN, E. N., CHATTERJEE, S. and MIKHAILOV, K. E. 2013. An embryonic enantiornithine bird and associated eggs from the Cretaceous of Mongolia. Paleontological Journal, 47, 1252-1269.

LAWVER, D. R. and BOYD, C. A. 2018. An avian eggshell from the Brule Formation (Oligocene) of North Dakota. Journal of Vertebrate Paleontology, 38, e1486848.

LIN, Y.-P. and SINGER, P. C. 2005. Inhibition of calcite crystal growth by polyphosphates. Water Research, 39, 4835-4843.

LONGRICH, N. R., PEREDA-SUBERBIOLA, X., JALIL, N.-E., KHALDOUNE, F. and JOURANi, E. 2017. An abelisaurid from the latest Cretaceous (late Maastrichtian) of Morocco, North Africa. Cretaceous Research, 76, 40-52.

LÓPEZ-MARTÍNEZ, N., CANUDO, J. I., ARDÉVOL, L., PEREDA-SUBERBIOLA, X., ORUE-ETXEBARRÍA, X., CUENCA-BESCÓS, G., RUIZ-OMENACA, J. I., MURELAGA, X. and FEIST, M. 2001. New dinosaur localities near the Cretaceous/Tertiary boundary (Arénsouth central Pyrenees, Spain). Cretaceous Research, 22, 41-61.

LOSOS, J. B. 2011. Convergence, adaptation, and constraint. Evolution, 65, 1827-1840.

MALAFAIA, E., MOCHO, P., ESCASO, F. and ORTEGA, F. 2017. A juvenile allosauroid theropod (Dinosauria, Saurischia) from the Upper Jurassic of Portugal. Historical Biology, 29, 654-676.

MARZOLA, M., RUSSO, J. and MATEUS, O. 2015. Identification and comparison of modern and fossil crocodilian eggs and eggshell structures. Historical Biology, 27, 115-133.

MATEUS, I., MATEUS, H., ANTUNES, M. T., MATEUS, O., TAQUET, P., RIBEIRO, V. and MANUPPELLA, G. 1997. Couvée, oeufs et embryons d'un Dinosaure Théropode du Jurassique supérieur de Lourinhã (Portugal). Comptes Rendus de L'Académie des Sciences Series IIA Earth and Planetary Science, 325, 71-78. [in Portuguese, English abstract]

MELINTE-DOBRINESCU, M. C. 2010. Lithology and biostratigraphy of Upper Cretaceous marine deposits from the Hațeg region (Romania): palaeoenvironmental implications. Palaeogeography, Palaeoclimatology, Palaeoecology, 293, 283294.

MEY, P. H. W., NAGTEGAAL, P. J. C., ROBERTi, K. J. and HARTELVELT, J. J. A. 1968. Lithostratigraphic subdivision of Post-Hercynian deposits in the South-Central Pyrenees, Spain. Leidse Geologische Mededelingen, 41, 221-228. 
MIKHAILOV, K. E. 1991. Classification of fossil eggshells of amniotic vertebrates. Acta Palaeontologica Polonica, 36, 193-238.

— 1996. Bird eggs in the Upper Cretaceous of Mongolia. Paleontological Journal, 30, 114-116.

- 1997a. Fossil and recent eggshell in amniotic vertebrates: fine structure, comparative morphology and classification. Special Papers in Palaeontology, 56, 1-80.

— 1997b. Avian eggshells: An atlas of scanning electron micrographs. British Ornithologists' Club Occasional Publications. 3, $88 \mathrm{pp}$.

2000. Eggs and eggshells of dinosaurs and birds from the Cretaceous of Mongolia. 560-572. In BENTON, M., SHISHKIN, M. A., UNWIN, D. and KUROCHKIN, E. N. (eds). The age of dinosaurs in Russia and Mongolia. Cambridge University Press, 740 pp.

— 2014. Eggshell structure, parataxonomy and phylogenetic analysis: some notes on articles published from 2002 to 2011. Historical Biology, 26, 144-154.

— BRAY, E. S. and HIRSCH, K. F. 1996. Parataxonomy of fossil egg remains (Veterovata): principles and applications. Journal of Vertebrate Paleontology, 16, 763-769.

MORENO-AZANZA, M., MARIANI, E., BAULUZ, B. and CANUDO, J. I. 2013. Growth mechanisms in dinosaur eggshells: an insight from electron backscatter diffraction. Journal of Vertebrate Paleontology, 33, 121-130.

— BAULUZ, B., CANUDO, J. I., PUÉRTOLAS - PASCUAL, E. and SELLÉS, A. G. 2014a. A re-evaluation of aff. Megaloolithidae eggshell fragments from the uppermost Cretaceous of the Pyrenees and implications for crocodylomorph eggshell structure. Historical Biology, 26, 195-205.

— CANUDO, J. I. and GASCA, J. M. 2014b. Unusual theropod eggshells from the Early Cretaceous Blesa Formation of the Iberian Range, Spain. Acta Palaeontologica Polonica, 59, 843-854.

— BAuluz, B., CANUdO, J. I., GASCA, J. M. and FERNÁNDEZ-BALDOR, F. 2016. Combined use of electron and light microscopy techniques reveals false secondary shell units in Megaloolithidae eggshells. PLoS One, 11, e0153026.

— $—$ and MATEUS O. 2017. The conservative structure of the ornithopod eggshell: electron backscatter diffraction characterization of Guegoolithus turolensis from the Early Cretaceous of Spain. Journal of Iberian Geology, 43, 235243.

ORTEGA, F., BARDET, N., BARROSO-BARCENILLA, F., CAllAPEZ, P. M., CAMBRA-MOO, O., DAVIERO-GÓMEZ, V., DÍEZ DÍAZ, V., DOMINGO, L., ELVIRA, A., ESCASO, F., GARCÍA-OLIVA, M., GÓMEZ, B., HOUSSAYE, A., KNOLL, F., MARCOSFERNÁNDEZ, F., MARTÍN, M., MOCHO, P., NARVÁEZ, I., PÉREZ-GARCÍA, A., PEYROT, D., SEGURA, M., SERRANO, H., TORRICES, A., VIDAL, D. and SANZ, J. L. 2015. The biota of the Upper Cretaceous site of Lo Hueco (Cuenca, Spain). Journal of Iberian Geology, 41, 83-99.

OSER, S. E. 2018. Campanian ooassemblages within the Western Interior Basin: eggshell from the Upper Cretaceous Kaiparowits Formation of Grand Staircase Escalante National
Monument, UT. Unpublished MSc thesis, University of Colorado, Boulder, CO, USA, 114 pp.

ŐSI, A., RABI, M., MAKÁDI, L., SZENTESI, Z., BOTFALVAI, G. and GULYÁS, P. 2012. The Late Cretaceous continental vertebrate fauna from Iharkút (Western Hungary): a review. 532-569. In GODEFROIT, P. (ed.) Bernissart dinosaurs and early Cretaceous terrestrial ecosystems. Indiana University Press, 648 pp.

PACKARD, M. J. and HIRSCH, K. F. 1989. Structure of shells from eggs of the geckos Gekko gecko and Phelsuma madagascarensis. Canadian Journal of Zoology, 67, 746-758.

PANAIOTU, C. G. and PANAIOTU, C. E. 2010. Palaeomagnetism of the Upper Cretaceous Sânpetru Formation (Hațeg Basin, South Carpathians). Palaeogeography, Palaeoclimatology, Palaeoecology, 293, 343-352.

PEREDA-SUBERBIOLOA, X., CANUDO, J. I., CRUZADO-CABALLERO, P., BARCO, J. L., LÓPEZMARTÍNEZ, N., OMS, O. and RUIZ-OMEÑACA, J. I. 2009. The last hadrosaurid dinosaurs of Europe: a new lambeosaurine from the Uppermost Cretaceous of Aren (Huesca, Spain). Comptes Rendus Palevol, 8, 559-572.

PÉREZ-GARCÍA, A., ORTEGA, F., BOLET, A., ESCASO, F., HOUSSAYE, A., MARTÍNEZ-SALANOVA, J., DE, MIGUEL CHAVES, C., MOCHO, P., NARVÁEZ, I., SEGURA, M., TORICES, A., VIDAL, D. and SANZ, J. L. 2016. A review of the upper Campanian vertebrate site of Armuña (Segovia Province, Spain). Cretaceous Research, 57, 591-623.

POL, C. A., BUSCALIONI, D., CARBAILlERA, J., FRANCÉS, V., LÓPEZ-MARTÍNEZ, N., MARANDAT, B., MORATALLA, J. J., SANZ, J. L., SIGÉ, B. and VILLATTE, J. 1992. Reptiles and mammals from the Late Cretaceous new locality Quintanilla del Coco (Burgos Province, Spain). Neues Jahrbuch für Geologie und Paläontologie Abhandlungen, 184, 279-314.

PRONDVAI, E., BOTFALVAI, G., STEIN, K., SZENTESI, Z. and ÖSI, A. 2017. Collection of the thinnest: a unique eggshell assemblage from the Late Cretaceous vertebrate locality of Iharkút (Hungary). Central European Geology, 60, 73-133.

PRUM, R. O., BERV, J. S., DORNBURG, A., FIELD, D. J., TOWNSEND, J. P., LEMMON, E. M. and LEMMON, A. R. 2015. A comprehensive phylogeny of birds (Aves) using targeted next-generation DNA sequencing. Nature, 526, 569-573.

PUÉRTOLAS-PASCUAL, E., ARENILLAS, I., ARZ, J. A., CALVÍN, P., EZQUERRO, L., GARCÍA-VICENTE, C., PÉREZ-PUEYO, M., SÁNCHEZ-MORENO, E. M., VILLALAÍN, J. J. and CANUDO, J. I. 2018. Chronostratigraphy and new vertebrate sites from the upper Maastrichtian of Huesca (Spain), and their relation with the K/Pg boundary. Cretaceous Research, 89, 36-59.

PYRON, R. A., BURBRINK, F. T. and WIENS, J. J. 2013. A phylogeny and revised classification of Squamata, including 4161 species of lizards and snakes. BMC Evolutionary Biology, 13, 93.

RIBEIRO, V., MATEUS, O., HOLWERDA, F., ARAÚJO, R. and CASTANHINHA, R. 2014. Two new theropod egg sites from the Late Jurassic Lourinhã Formation, Portugal. Historical Biology, 26, 206-217. 
SAHNI, A., TANDON, S. K., JOLLY, A., BAJPAY, S., SOOD, A. and SRINIVASAN, S. 1994. Upper Cretaceous dinosaur eggs and nesting sites from the Deccan volcano-sedimentary province of peninsular India. 204-226. In CARPENTER, K., HIRSCH, K. F. and HORNER, J. R. (eds). Dinosaur eggs and babies. Cambridge University Press, 392 pp.

SALLAM, H. M., O'CONNOR, P. M., KORA, M., SERTICH, J. J. W., SEIFFERT, E. R., FARIS, M., OUDA, K., EL-DAWOUDI, I., SABER, S. and EL-SAYED, S. 2016. Vertebrate paleontological exploration of the Upper Cretaceous succession in the Dakhla and Kharga Oases, Western Desert, Egypt. Journal of African Earth Sciences, 117, 223-234.

GORSCAK, E., O'CONNOR, P. M., ELDAWOUDI, I. A., EL-SAYED, S., SABER, S., KORA, M. A., SERTICH, J. J. W., SEIFFERT, E. R. and LAMANNA, M. C. 2018. New Egyptian sauropod reveals Late Cretaceous dinosaur dispersal between Europe and Africa. Nature Ecology \& Evolution, 2, 445-451.

SANDER, P. M. 2012. Reproduction in early amniotes. Science, 337, 806-808.

SCHLEICH, H. H. and KÄSTLE, W. 1988. Reptile egg-shells SEM atlas. Gustav Fischer Verlag, Stuttgart, 123 pp.

SELLÉS, A. G. 2012. Oological record of dinosaur in SouthCentral Pyrenees (SW Europe): parataxonomy, diversity and biostratigraphical implications. Unpublished $\mathrm{PhD}$ thesis, Universitat de Barcelona, Barcelona, Spain, 231 pp.

— and VILA, B. 2015. Re-evaluation of the age of some dinosaur localities from the southern Pyrenees by means of megaloolithid oospecies. Journal of Iberian Geology, 41, 125-139.

— _ and GALOBART À. 2014. Diversity of theropod ootaxa and its implications for the latest Cretaceous dinosaur turnover in southwestern Europe. Cretaceous Research, 49, 45-54.

ShUBIN, N., TABIN, C. and CAROLL, S. 2009. Deep homology and the origins of evolutionary novelty. Nature, 457, 818-823.

SIMON, D. J., VARRICCHIO, D. J., JIN, X. and ROBISON, S. F. 2019. Microstructural overlap of Macroelongatoolithus eggs from Asia and North America expands the occurrence of colossal oviraptorosaurs. Journal of Vertebrate Paleontology, 38, e1553046.

SKAWIŃSKI, T. and TAŁANDA, M. 2014. Integrating developmental biology and the fossil record of reptiles. The International Journal of Developmental Biology, 58, 949-959.

STEIN, K., PRONDVAI, E., HUANG, T., BAELE, J.-M., SANDER, P. M. and REISZ, R. 2019. Structure and evolutionary implications of the earliest (Sinemurian, Early Jurassic) dinosaur eggs and eggshells. Scientific Reports, 9, 4424.

TANAKA, K., ZELENITSKY, D. K., WILLIAMSON, T., WEIL, A. and THERRIEN, F. 2011. Fossil eggshells from the Upper Cretaceous (Campanian) Fruitland Formation, New Mexico. Historical Biology, 23, 41-55.

— $—$ and THERRIEN F. 2015. Eggshell porosity provides insight on evolution of nesting in dinosaurs. PLoS One, 10, e0142829.

— - SAEGUSA, H., IKEDA, T., DEBUHR, C. L. and THERRIEN, F. 2016. Dinosaur eggshell assemblage from Japan reveals unknown diversity of small theropods. Cretaceous Research, 57, 350-363.
KOBAYASHI, Y., ZELENITSKY, D. K., THERRIEN, F., LEE, Y.-N., BARSBOLD, R., KUBOTA, K., LEE, H.-J., CHINZORIG, T. and IDERSAIKHAN, D. 2019. Exceptional preservation of a Late Cretaceous dinosaur nesting site from Mongolia reveals colonial nesting behavior in a non-avian theropod. Geology, 47, 843-847.

TORICES, A., CURRIE, P. J., CANUDO, J. I. and PEREDA-SUBERBIOLA, X. 2015. Theropod dinosaurs from the Upper Cretaceous of the South Pyrenees Basin of Spain. Acta Palaeontologica Polonica, 60, 611-626.

VALENTIN, X., GODEFROIT, P., TABUCE, R., VIANEYLIAUD, M., WU, W.-H. and GARCIA, G. 2012. First Late Maastrichtian (latest Cretaceous) vertebrate assemblages from Provence (Vitrolles-la-Plaine, southern France). 582-597. In GODEFROIT, P. (ed.) Bernissart dinosaurs and Early Cretaceous terrestrial ecosystems. Indiana University Press.

VAN ITTERBEECK, J., MARKEVICH, V. S. and CODREA, V. 2005. Palynostratigraphy of the Maastrichtian dinosaur- and mammal sites of the Râul Mare and Barbat Valleys (Hațeg Basin, Romania). Geologica Carpathica, 56, 137-147.

VARRICCHIO, D. J. and BARTA, D. E. 2015. Revisiting Sabath's "Larger Avian Eggs" from the Gobi Cretaceous. Acta Palaeontologica Polonica, 60, 11-25.

— and JACKSON, F. D. 2004. A phylogenetic assessment of prismatic dinosaur eggs from the Cretaceous Two Medicine Formation of Montana. Journal of Vertebrate Paleontology, 24, 931-937.

— 2016. Reproduction in Mesozoic birds and evolution of the modern avian reproductive mode. Auk, 133, 654-684.

BALANOFF, A. M. and NORELL, M. A. 2015. Reidentification of avian embryonic remains from the Cretaceous of Mongolia. PLoS One, 10, e0128458.

VASILE, Ș. 2010. Noi situri cu microvertebrate din Maastrichtianul Formațiunii de Densuș-Ciula în Bazinul Hațeg. 9093. In Al X-lea Simpozion Național Studențesc "Geoecologia”. Petroșani, Romania.

— and CSIKI-SAVA, Z. 2010. Comparative paleoecological analysis of some microvertebrate fossil assemblages from the Hațeg Basin, Romania. Oltenia. Studii și Comunicări. Științele Naturii, 26, 315-322.

— 2011. New Maastrichtian microvertebrates from the Rusca Montană Basin (Romania). Oltenia. Studii și Comunicări. Știintele Naturii, 27, 221-230.

—— and GRIGORESCU D. 2011a. Reassessment of the spatial extent of the Middle Member, Densuş-Ciula Formation (Maastrichtian), Hațeg Basin, Romania. Acta Palaeontologica Romaniae, 7, 335-342.

- ZAHARIA, A., CSIKI, Z. and GRIGORESCU, D. $2011 b$. The first report of continental fossil remains from Crăguiș (Hațeg Basin, Romania), and their stratigraphical significance. 127-128. In CSIKI, Z. (ed.) Abstract Book, 8th Romanian Symposium on Paleontology. Ars Docendi, Bucharest.

- GRIGORESCU, D. and CSIKI-SAVA, Z. 2012. Maastrichtian continental microvertebrates from Fărcădeana (Rusca Montană Basin, Romania). 271-273. In ROYO-TORRES, R., GASCÓ, F. and ALCALÁ, L. (eds). 10th Annual Meeting 
of the European Association of Vertebrate Palaeontologists, Teruel.

VIANEY-LIAUD, M. and CROCHET, J.-Y. 1993. Dinosaur eggshells from the Late Cretaceous of Languedoc (southern France). Revue de Paléobiologie, 7, 237-249.

— and GARCIA, G. 2003. Diversity among North African dinosaur eggshells. Palaeovertebrata, 32, 171-188.

_ and LOPEZ-MARTINEZ, N. 1997. Late Cretaceous dinosaur eggshells from the Tremp Basin, Southern Pyrenees, Lleida, Spain. Journal of Paleontology, 71, 1157-1171.

— HIRSCH, K., SAHNI, A. and SIGÉ, B. 1997. Late Cretaceous Peruvian eggshells and their relationships with Laurasian and eastern Gondwanian material. Geobios, 30, 75-90.

VILA, B., SEllÉS, A. G. and BRUSATTE, S. L. 2016. Diversity and faunal changes in the latest Cretaceous dinosaur communities of southwestern Europe. Cretaceous Research, 57, 552-564.

VOICU, S. M., VASILE, Ș. and CSIKI-SAVA, Z. 2018. The Cretaceous swamp just gets bigger: new data on the faunal composition of the Pui Swamp microvertebrate bonebed, Maastrichtian of the Hațeg Basin. 152-153. In POPA, L. O., ADAM, C., CHIŞAMERA, G., IORGU, E., MURARIU, D. and POPA, O. P. (eds). 9th International Zoological Congress of "Grigore Antipa" Museum, Bucharest.

VORIS, J. T., ZELENITSKY, D. K., THERRIEN, F. and TANAKA, K. 2018. Dinosaur eggshells from the lower Maastrichtian St. Mary River Formation of southern Alberta, Canada. Canadian Journal of Earth Sciences, 55, 272-282.

VREMIR, M. 2010. New faunal elements from the Late Cretaceous (Maastrichtian) continental deposits of Sebeș area (Transylvania). Terra Sebus. Acta Musei Sabesiensis, 2, 635-684.

— BĂLC, R., CSIKI-SAVA, Z., BRUSATTE, S. L., DYKE, G., NAISH, D. and NORELL, M. A. 2014. Petrești-Arini: an important but ephemeral Upper Cretaceous continental vertebrate site in the southwestern Transylvanian Basin, Romania. Cretaceous Research, 49, 13-38.

— DYKE, G. and TOTOIANU, R. 2015a. Repertoire of the Late Cretaceous vertebrate localities from Sebeș area, Alba County (Romania). Terra Sebus. Acta Musei Sabesiensis, 7, 695-724.

— VASILE, Ș., TOTOIANU, R., DYKE, G. and CSIKISAVA, Z. 2015b. Never say never: new additions to the composition of the oldest latest Cretaceous continental vertebrate assemblage in Transylvania, western Romania. 73. In JAGT, J. W. M., HEBDA, G., Mitrus, S., JAGT-
YAZYKOVA, E. A., BODZIOCH, A., KONIETZKOMEIER, D., KARDINAL, K. and GRUNTMEJER, K. (eds). Abstracts, 13th Annual Meeting of the European Association of Vertebrate Palaeontologists, Opole.

WEISHAMPEL, D. B., BARRETT, P. M., CORIA, R. A., LE LOEUFF, J., XU, X., ZHAO, X.-J., SAHNI, A., GOMANI, E. and NOTO, C. R. L. 2004. Dinosaur distribution. 517-606. In WEISHAMPEL, D. B., DODSON, P. and OSMÓLSKA, H. (eds). The Dinosauria, California University Press.

WELSH, E. and SANKEY, J. T. 2008. First dinosaur eggshells from Texas, USA: Aguja Formation (Late Campanian), Big Bend National Park. 166-177. In SANKEY, J. T. and BASZIO, S. (eds). Vertebrate microfossil assemblages. Indiana University Press, 296 pp.

WHEELER, J., PRIOR, D. J., JIANG, Z., SPIESS, R. and TRIMBY, P. W. 2001. The petrological significance of misorientations between grains. Contributions to Mineralogy \& Petrology, 141, 109-124.

WIEMANN, J., YANG, T.-R. and NORELL, M. A. 2018. Dinosaur egg colour had a single evolutionary origin. Nature, 563, 555-558.

ZELENITSKY, D. K. and MODESTO, S. P. 2003. New information on the eggshell of ratites (Aves) and its phylogenetic implications. Canadian Journal of Zoology, 81, 962-970.

- and SLOBODA, W. 2005. Eggshells. 398-404. In CURRIE, P. J. and KOPPELHUS, E. B. (eds). Dinosaur Provincial Park: A spectacular ancient ecosystem revealed. Indiana University Press, 672 pp.

- HILLS, L. V. and CURRIE, P. J. 1996. Parataxonomic classification of ornithoid eggshell fragments from the Oldman Formation (Judith River Group; Upper Cretaceous), southern Alberta. Canadian Journal of Earth Sciences, 33, 1655-1667.

- MOdesto, S. P. and CURRIE, P. J. 2002. Bird-like characteristics of troodontid theropod eggshell. Cretaceous Research, 23, 297-305.

- THERRIEN, F., TANAKA, K., CURRIE, P. J. and DEBUHR, C. L. 2017a. Latest Cretaceous eggshell assemblage from the Willow Creek Formation (upper Maastrichtian - lower Paleocene) of Alberta, Canada, reveals higher dinosaur diversity than represented by skeletal remains. Canadian Journal of Earth Sciences, 54, 134-140.

- KOBAYASHI, Y. and DEBUHR, C. L. 2017b. Dinosaur eggshells from the Santonian Milk River Formation of Alberta, Canada. Cretaceous Research, 74, 181-187. 